\title{
Investigation of Submarine Groundwater Discharge along the Tidal Reach of the Caloosahatchee River, Southwest Florida
}

By Christopher D. Reich

Prepared in cooperation with the

South Florida Water Management District

Open-File Report 2009-1273 


\title{
U.S. Department of the Interior \\ KEN SALAZAR, Secretary \\ U.S. Geological Survey \\ Marcia K. McNutt, Director
}

\section{U.S. Geological Survey, Reston, Virginia: 2009}

\author{
For more information on the USGS - the Federal source for science about the Earth, its natural and living resources, \\ natural hazards, and the environment, visit http://www.usgs.gov or call 1-888-ASK-USGS \\ For an overview of USGS information products, including maps, imagery, and publications, \\ visit http://www.usgs.gov/pubprod \\ To order this and other USGS information products, visit http://store.usgs.gov
}

\begin{abstract}
Any use of trade, product, or firm names is for descriptive purposes only and does not imply endorsement by the U.S. Government.

Although this report is in the public domain, permission must be secured from the individual copyright owners to reproduce any copyrighted materials contained within this report.
\end{abstract}

Suggested citation:

Reich, C.D., 2010, Investigation of Submarine Groundwater Discharge along the Tidal Reach of the Caloosahatchee River, Southwest Florida: U.S. Geological Survey Open-File Report 2009-1273, 20 p., plus apps., p. A1-A52. 


\section{Contents}

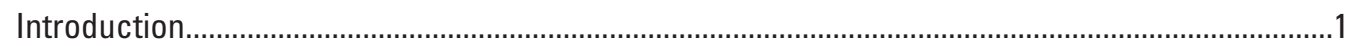

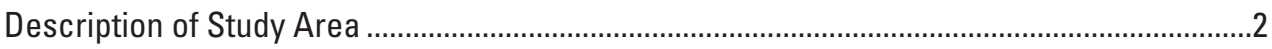

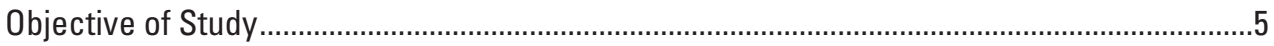

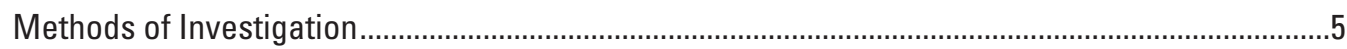

Continuous Surface-Water Mapping ….........................................................................

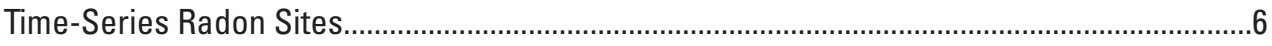

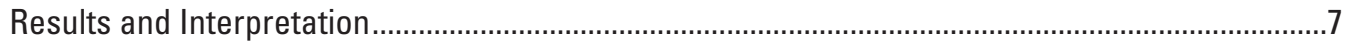

Continuous Radon Mapping.....................................................................................................

Time-Series Radon and Groundwater Discharge Estimates ................................................11

Whiskey Creek Site ................................................................................................. 11

Lock and Dam Site (S-79) .........................................................................................

Comparison with other Florida Sites ...............................................................................15

Continuous Resistivity Profiling Surveys ................................................................................ 15

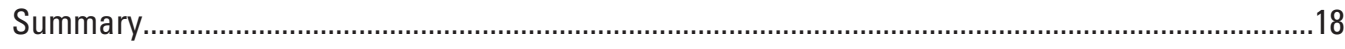

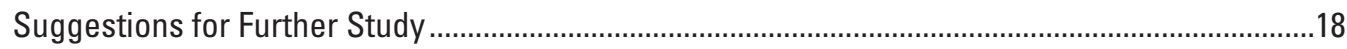

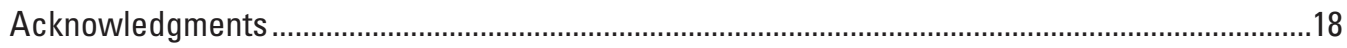

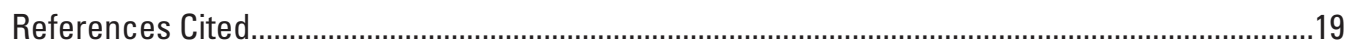

Appendix - Continuous Resistivity Profile image segments collected in the

Caloosahatchee River

A1-A52

\section{Figures}

1. Map of Caloosahatchee River study area in Lee County, Florida ................................................

2. Map of Lee County, Florida, showing location of the Caloosahatchee River relative to the Gulf of Mexico, time-series radon locations, and W.P. Franklin Lock and Dam (S-79).

3. Graph showing rainfall and W.P. Franklin Lock and Dam (S-79) water releases relative to study period of March 15 to 20, 2009 ........................................................................

4. Map showing the surficial geology of the Lee County region ........................................................4

5. Photo of the R/V Halimeda and the equipment used for continuous radon

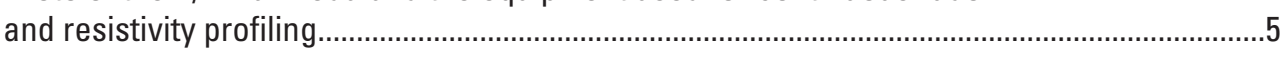

6. Conceptual box model of radon inflows and losses to a coastal water body where inventory is measured over time, and total flux is calculated by adjusting

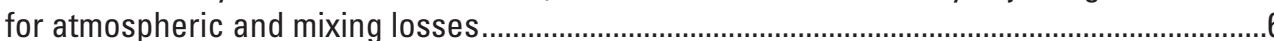

7. Continuous ${ }^{222} \mathrm{Rn}$ map showing an increase in radon activity from near the mouth

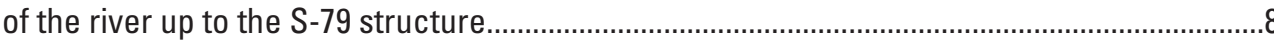

8. Graph with table showing normalized radon per volume of river for the three river

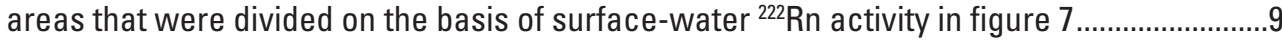

9. Graph showing tidal signal collected by the NOAA gaging station located beneath the US-41 (Edison) bridge on the Caloosahatchee River ..........................................................

10. Map showing continuous surface-water salinity values collected during radon and resistivity surveys .

11. Map showing continuous surface-water temperature values collected during radon and resistivity surveys. 
12. Photo showing time-series radon equipment at the Whiskey Creek site .....

13. Graphs of ${ }^{222} \mathrm{Rn}$ in water, ${ }^{222} \mathrm{Rn}$ net flux, and advective flux at the Whiskey Creek time-series site, March 15-19, 2009.

14. Photo showing the S-79 time-series site shows the R/V Halimeda used as the platform for collecting radon and surface-water data, and the piezometer and pump used to collect porewater and radon samples.

15. Graphs of ${ }^{222} \mathrm{Rn}$ in water, ${ }^{222} \mathrm{Rn}$ net flux, and advective flux at the $\mathrm{S}-79$ time-series site on March 19, 2009

16. Graph showing vertical profile of surface-water and porewater salinity and ${ }^{222} \mathrm{Rn}$ collected at the S-79 time-series site.

17. Map showing individual segments of continuous resistivity profiles collected in the Caloosahatchee River...

\section{Tables}

1. Table of porewater ${ }^{222} \mathrm{Rn}$, salinity, and temperature collected at two sites during the time-series experiment near lock and dam structure S-79....

2. Variability in advective fluxes and methods by which fluxes are derived for different sites within Florida. 


\section{Conversion Factors}

\begin{tabular}{rcl}
\hline Multiply inch/pound units & by & To obtain SI units \\
\hline & Length & \\
inch (in.) & 2.54 & centimeter $(\mathrm{cm})$ \\
foot $(\mathrm{ft})$ & 0.3048 & meter $(\mathrm{m})$ \\
mile $(\mathrm{mi})$ & 1.609 & kilometer $(\mathrm{km})$ \\
& 1.852 & kilometer $(\mathrm{km})$ \\
& Volume & \\
mile, nautical (nmi) & \\
gallon $(\mathrm{gal})$ & 3.785 & liter $(\mathrm{L})$ \\
gallon $(\mathrm{gal})$ & 0.003785 & cubic meter $\left(\mathrm{m}^{3}\right)$ \\
cubic inch (in $\left.\mathrm{in}^{3}\right)$ & 16.39 & cubic centimeter $(\mathrm{cm} 3)$ \\
cubic inch $\left(\mathrm{in}^{3}\right)$ & 0.01639 & liter $(\mathrm{L})$ \\
cubic foot $\left(\mathrm{ft}^{3}\right)$ & 0.02832 & cubic meter $\left(\mathrm{m}^{3}\right)$ \\
gallon per day $(\mathrm{gal} / \mathrm{d})$ & 0.003785 & cubic meter per day $\left(\mathrm{m}^{3} / \mathrm{d}\right)$ \\
mile per hour $(\mathrm{mi} / \mathrm{h})$ & 1.609 & kilometer per hour $(\mathrm{km} / \mathrm{h})$ \\
\hline & &
\end{tabular}

\section{Acronyms and Abbreviations}

\footnotetext{
SGD submarine groundwater discharge

CRP continuous resistivity profiling

kph kilometers per hour

ppt parts per thousand (salinity unit)

$\mathrm{dpm} / \mathrm{L}$ disintegrations per minute per liter

$\mathrm{dpm} / \mathrm{m}^{3} \quad$ disintegrations per minute per cubic meter

$\mathrm{dpm} / \mathrm{m}^{2}$ disintegrations per minute per square meter

$\mathrm{cm} / \mathrm{d}$ centimeters per day

USGS U.S. Geological Survey

SFWMD South Florida Water Management District

YSI Yellow Springs, Inc.

GPS Global Positioning System

WAAS Wide Area Augmentation System
}

\begin{tabular}{rl|l} 
ohm-m & ohm-meter \\
$\mathrm{cm}$ & centimeter \\
$\mathrm{m}$ & meter \\
$\mathrm{km}$ & kilometer \\
${ }^{\circ} \mathrm{C}$ & degrees Celsius \\
$\mathrm{min}$ & minute \\
$\mathrm{hr}$ & hour \\
$\mathrm{s}$ & second \\
$\mathrm{n}$ & number of observations \\
$\sim$ & approximately \\
$>$ & greater than \\
$<$ & less than \\
$\mathrm{R} / \mathrm{V}$ & research vessel
\end{tabular}





\title{
Investigation of Submarine Groundwater Discharge along the Tidal Reach of the Caloosahatchee River, Southwest Florida
}

\author{
By Christopher D. Reich
}

\section{Introduction}

The tidal reach of the Caloosahatchee River is an estuarine habitat that supports a diverse assemblage of biota including aquatic vegetation, shellfish, and finfish. The system has been highly modified by anthropogenic activity over the last 150 years (South Florida Water Management District (SFWMD), 2009). For example, the river was channelized and connected to Lake Okeechobee in 1881 (via canal C-43). Subsequently, three control structures (spillway and locks) were installed for flood protection (S-77 and S-78 in the 1930s) and for saltwater-intrusion prevention (S-79, W.P. Franklin Lock and Dam in 1966). The emplacement of these structures and their impact to natural water flow have been blamed for water-quality problems downstream within the estuary (Flaig and Capece, 1998; SFWMD, 2009). Doering and Chamberlain (1999) found that the operation of these control structures caused large and often rapid variations in salinity during various times of the year. Variable salinities could have deleterious impacts on the health of organisms in the Caloosahatchee River estuary.

Flow restriction along the Caloosahatchee has also been linked to surface-water eutrophication problems (Doering and Chamberlain, 1999; SFWMD, 2009) and bottom-sediment contamination (Fernandez and others, 1999). Sources of nutrients (nitrogen and phosphorous) that cause eutrophication are primarily from residential sources and agriculture, though wastewater-treatment-plant discharges can also play a major role (SFWMD, 2009). The pathway for many of these nutrients is by land runoff and direct discharge from stormwater drains. An often overlooked source of nutrients and other chemical constituents is from submarine groundwater discharge (SGD). SGD can be either a diffuse or point source (for example, submarine springs) of nutrients and other chemical constituents to coastal waters (Valiela and others, 1990; Swarzenski and others, 2001; 2006; 2007; 2008). SGD can be composed of either fresh or marine water or various mixed ratios of fresh and marine water (Martin and others, 2007). In coastal areas where water-table elevations (hydraulic gradients) are steep, such as in Hood Canal, Washington (Swarzenski and others, 2007; Simonds and others, 2008), groundwater entering the coastal marine waters can be fresh ( 1-4 parts per thousand, ppt). SGD in coastal locations that have low relief (low hydraulic gradients) such as the study area or other locations in Florida are typically driven by tidal pumping (Reich and others, 2002; 2008; Swarzenski and others, 2008), and water advecting into surface water is composed of recirculated marine water mixed with either fresh or brackish groundwaters.

The importance of SGD in the delivery of nutrients and trace elements to coastal environments has been shown to be both beneficial and deleterious to ecosystem health (Valiela and others, 1990). The logical step in studying SGD is to map areas where SGD occurs. Methods such as continuous surface-water radon-222 $\left({ }^{222} \mathrm{Rn}\right)$ mapping and electrical 
resistivity (continuous resistivity profiles, CRP) have been developed and used to identify potential SGD sites (Dulaiova and others, 2005; Swarzenski and others 2004; 2006; 2007; 2008; Reich and others, 2008). CRP data record subsurface, bulk-resistivity measurements to depths up to 25 meters (m). The bulk resistivity can be representative of changes in porewater salinity or in lithology (Reich and others, 2008; Swarzenski and others, 2008). Radon-222 (half-life $=3.28$ days) is a natural tracer of groundwater, because sediments and rocks, containing uranium-bearing materials such as limestone and phosphatic material, continually produce ${ }^{222} \mathrm{Rn}$. $\mathrm{Rn}-222$ (also referred to simply as radon) is an ideal tracer, because there is a constant source. Since radon is a gas, ${ }^{222} \mathrm{Rn}$ does not build up in the surface water but rather evades directly to the atmosphere (Burnett and Dulaiova, 2003; Burnett and others, 2003; Dulaiova and Burnett, 2006).

\section{Description of Study Area}

The tidal reach of the Caloosahatchee River investigated during this study is located in Lee County, Florida (fig. 1). The tidal portion of the Caloosahatchee River runs from San Carlos Bay (mouth of the river) to the W.P. Franklin Lock and Dam structure (S-79), an approximate length of 42 kilometers (km) (fig. 2; SFWMD, 2009). The densely populated communities of Cape Coral and Fort Myers occur along the lower portion of the river, while the upper section, located east of Interstate 75 (I-75) is mostly agricultural. The population and population density of Lee County, located in southwest Florida along the Gulf of Mexico, are 593,136 and 211 persons per square kilometer, respectively (U.S. Census Bureau, 2009). The majority of the population is located in the cities of Cape Coral and Fort Myers.

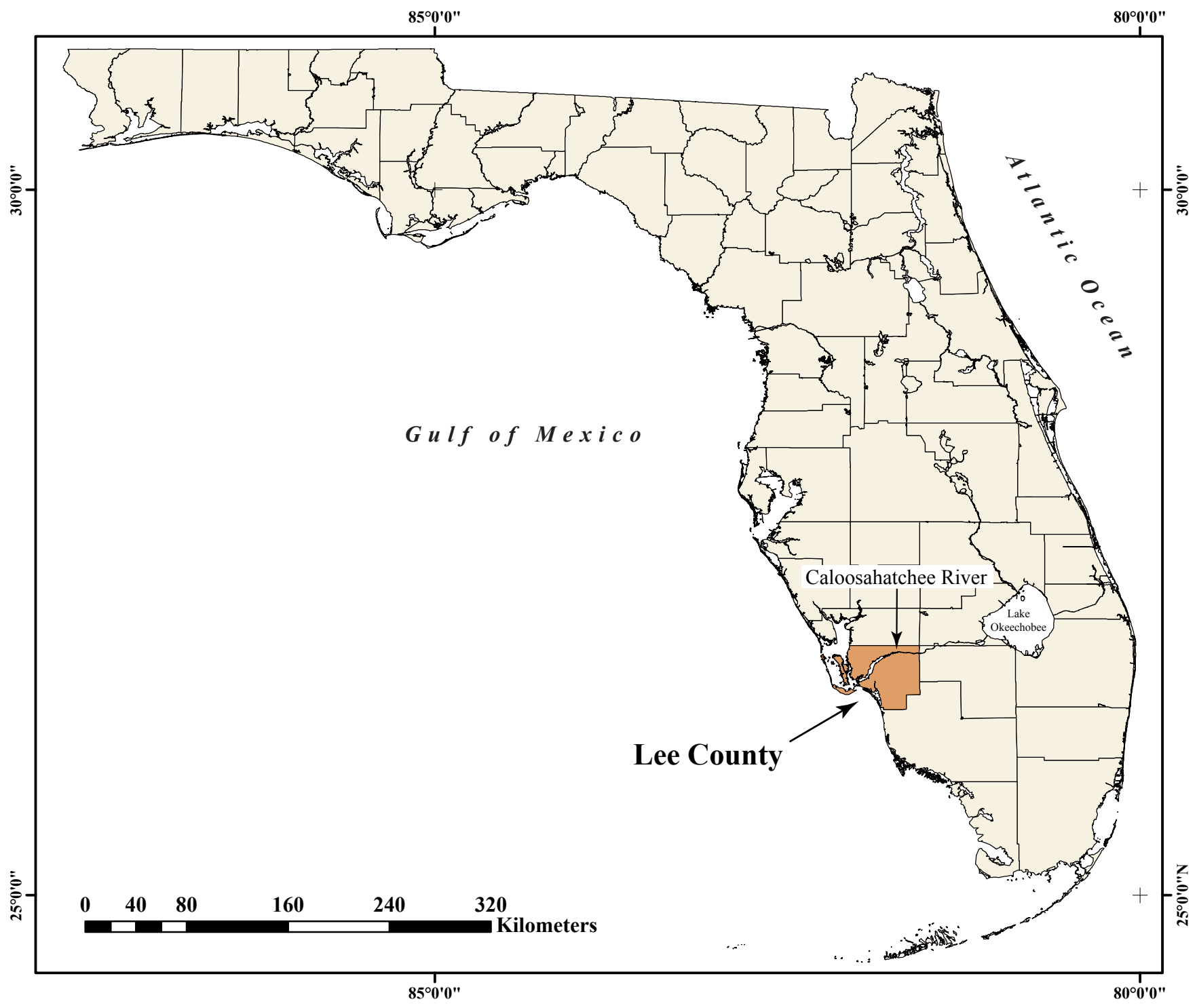

Figure 1. Caloosahatchee River study area in Lee County, Florida 




Figure 2. Lee County, Florida, showing location of the Caloosahatchee River relative to the Gulf of Mexico, time-series radon locations, and W.P. Franklin Lock and Dam (S-79).

The Caloosahatchee River is located in a subtropical climate with an average annual rainfall of 134 centimeters (cm) (53 inches, in.) (SFWMD, 2009). Rainfall average for January thru April 2009 was $3.8 \mathrm{~cm}$ (1.52 in.), which falls well below the average total (1976-2005) for the 4 months (24 cm; 9 in.) (Lee County Government, http://lee-county. com). Figure 3 shows rainfall events and water releases from S-79 from June 1, 2008, to April 1, 2009, as well as a marker identifying the study period (March 15-20, 2009).

The surficial geology of the study area is composed of an undifferentiated quartz-sand unit (Pleistocene-Holocene; $\mathrm{Qu}$ ), shelly units mixed with quartz sand and marly limestone (Tertiary-Quaternary shelly units; TQsu), and mixed siliciclastics and carbonate lithologies consisting of sandy limestone, quartz sand, and clayey sands (Tt; Tamiami Formation) (fig. 4; Missimer, 1978, 1999; Boggess and others, 1981; Scott, 2001;). The Qu unit acts as the primary surficial unconfined aquifer system throughout the study area. Water-table elevation maps (potentiometric maps) of Lee County show that water elevations can be as much as

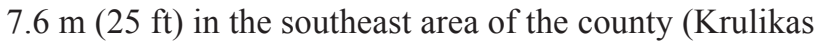
and Giese, 1995). The high water-table elevation is due to an increase in land-surface elevation in the same area. Water-table elevation closer to the Caloosahatchee River

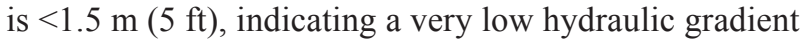
pushing groundwater into the river. However, east of I-75, the contours of water-table elevation along the northern shore of the river are more closely spaced and run parallel to the river. The more closely spaced contours indicate a greater hydraulic gradient, which could potentially result in greater baseflow or discharge into the river via SGD. The upper Floridan aquifer could be another potential source of groundwater to the 


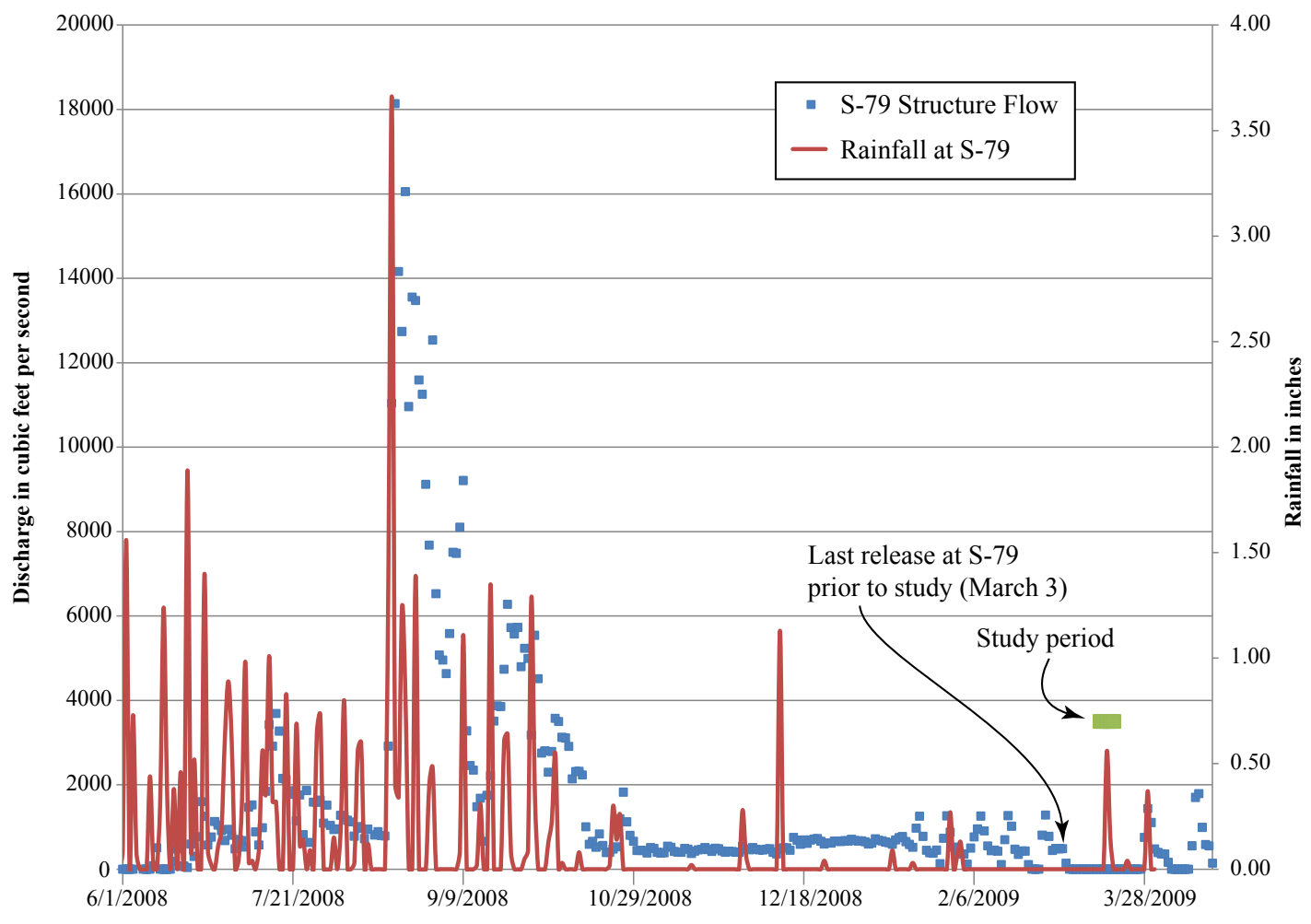

Figure 3. Rainfall (red line) and W.P. Franklin Lock and Dam (S-79) water releases (blue squares) relative to study period of March 15 to 20, 2009 (green bar). Data were obtained from gauging station located at the S-79 structure.

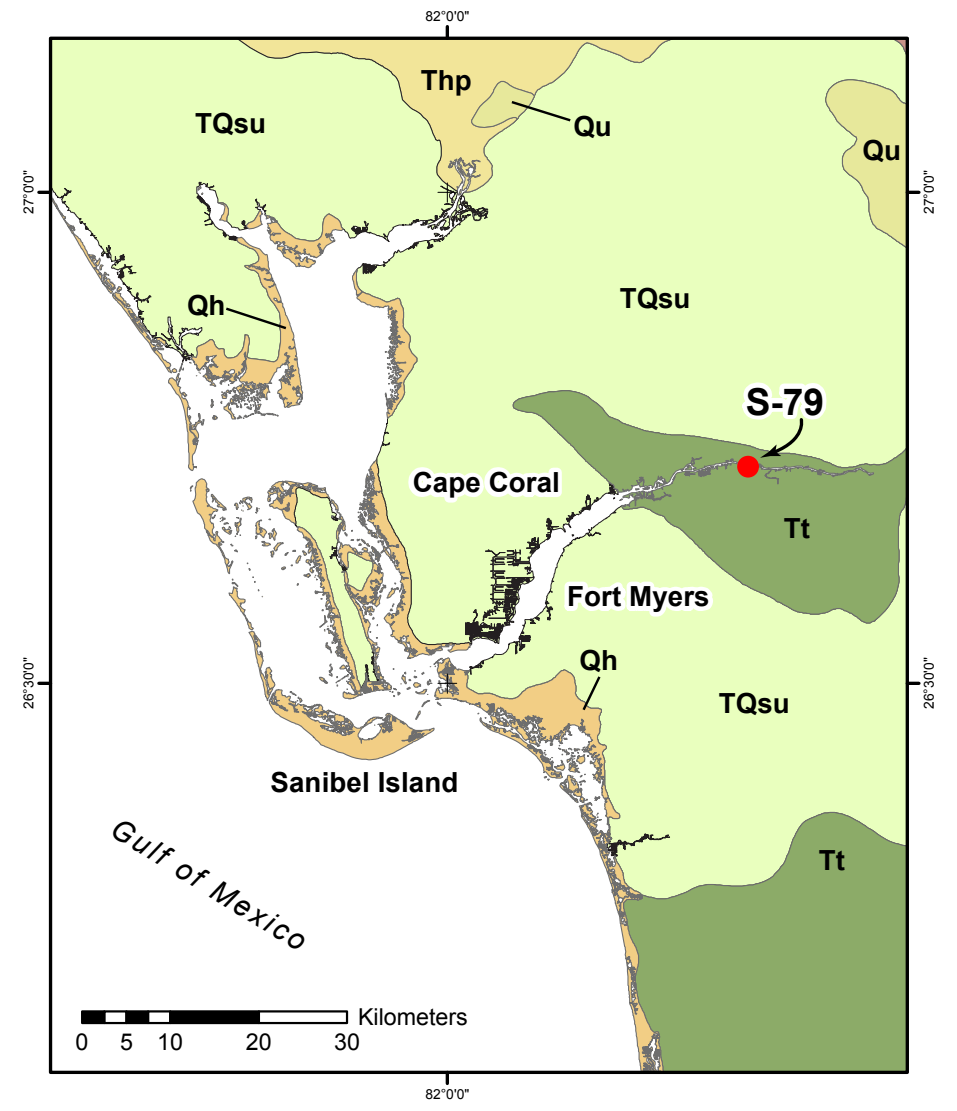

Figure 4. Surficial geology of the Lee County region (modified from Scott, 2001). [Geologic units (Scott, 2001) are as follows: Thp=MiocenePliocene, Hawthorn Group, Peace River Formation; $\mathrm{Tt}=$ Pliocene, Tamiami Formation; TQsu=Pliocene, Tertiary-Quaternary shell units; $\mathrm{Qu}=$ PleistoceneHolocene, undifferentiated sediments; and $\mathrm{Qh}=$ Holocene quartz and carbonate sands] 
Caloosahatchee River basin. Although Lee County has few groundwater wells to be used in constructing upper Floridan aquifer potentiometric maps, Ortiz (2008) has demonstrated that significant head potential exists in the region. Water in a completely cased well to the upper Floridan aquifer would rise between 12 and $15 \mathrm{~m}$ (40 and $50 \mathrm{ft}$ ) above land surface. This significant hydraulic head could result in leakage into overlying surface water through fractures/ faults in the confining units. However, leakage likely does not occur because the intermediate and Tamiami confining units are impermeable and provide isolation between the upper Floridan aquifer and surficial aquifer (Missimer, 1999; Cunningham and others, 2001).

\section{Objective of Study}

The objectives of this study were to identify locations of potential groundwater discharge into the estuary/river system and to quantify advective groundwater influxes. To accomplish these objectives, we collected continuous surface-water radon $\left({ }^{222} \mathrm{Rn}\right)$ and continuous resistivity profiles (CRP) along the tidal reaches of the Caloosahatchee River (figs. 1 and 2). Two stationary time-series radon surveys were also conducted to localize groundwater discharge inflow (advective fluxes) to the Caloosahatchee River.

\section{Methods of Investigation}

\section{Continuous Surface-Water Mapping}

Surface-water mapping of radon $\left({ }^{222} \mathrm{Rn}\right)$ and electrical resistivity (CRP) took place from the U.S. Geological Survey 7.5-m-long R/V Halimeda (fig. 5). The radon equipment consisted of a pole-mounted bilge pump set approximately $0.5 \mathrm{~m}$ below the water surface that continuously fed water to an air-water exchanger. The water was forced through a small spray nozzle and misted, releasing radon gas. Approximately 130-line-km of radon and resistivity data were collected. Continuous surface-water ${ }^{222} \mathrm{Rn}$ mapping is designed to obtain an image (qualitative investigation) of coastal areas where groundwater, observed as an increase in ${ }^{222} \mathrm{Rn}$, discharges into surface water. Due to instrument limitations, this method integrates over 10 minutes ( $\mathrm{min}$ ), which equates to a distance of $\sim 700 \mathrm{~m}$ at a boat speed of $\sim 4$ kilometers per hour (kph).

The internal air pumps of the radon-monitoring device (RAD7; Durridge Company Inc.) pulled air from the air-water exchanger through small-diameter tubing connected to the top of the air-water exchanger into a box where the air passed through a column containing a drying agent, reducing the humidity to approximately 6 percent. The dry air was then

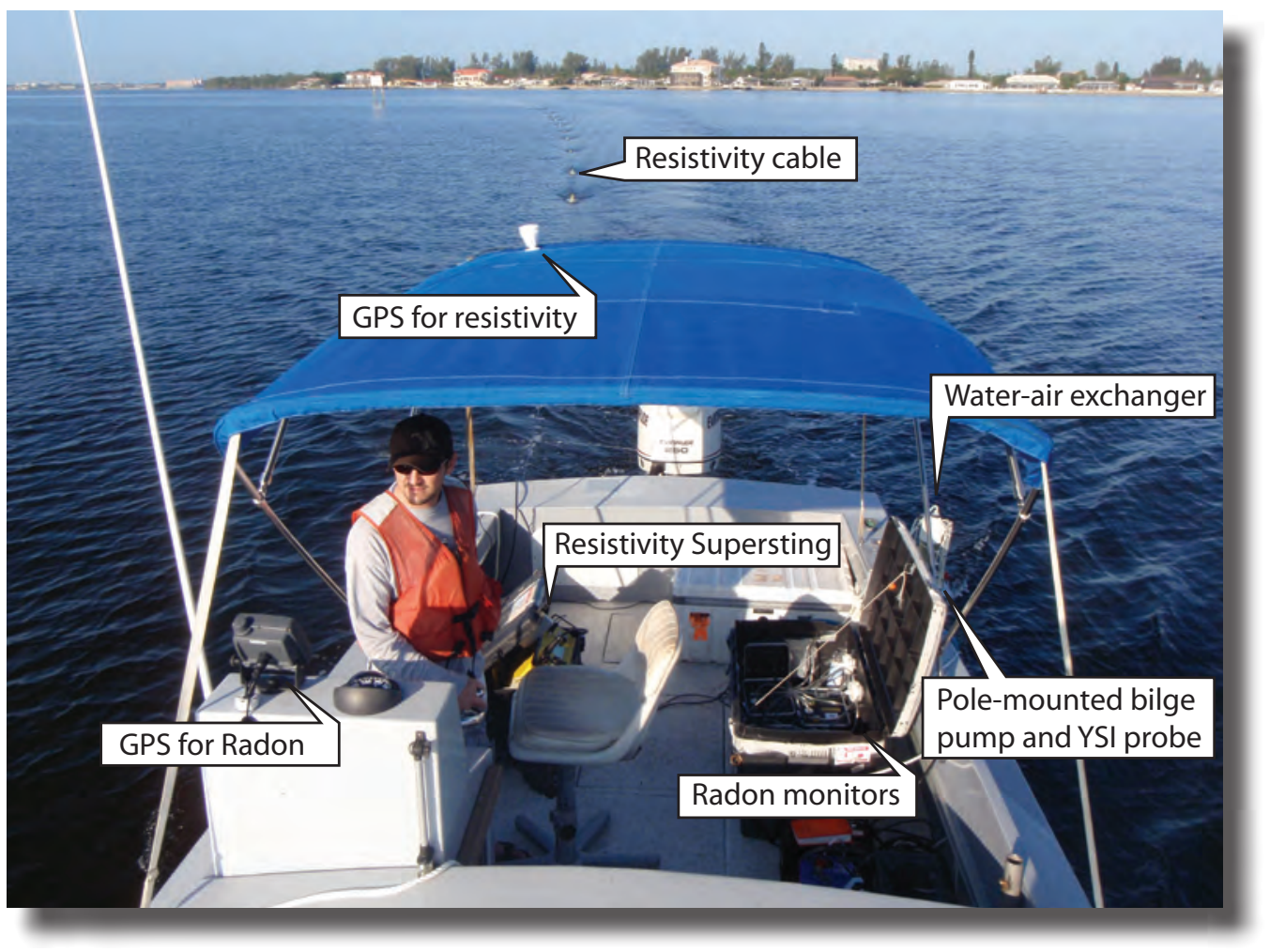

Figure 5. The R/V Halimeda and the equipment used for continuous radon and resistivity profiling. [YSI, Yellow Springs, Inc.] 
fed into a series of RAD7s (4 connected in series; fig. 5) where the radon was counted by a solid-state (silicon) alpha detector. As alpha particles are emitted, the RAD7 counts them and measures the ${ }^{222} \mathrm{Rn}$ activity (Burnett and others, 2001; Dulaiova and others, 2005). Surface-water data were also collected with a YSI 556 MPS mulit-probe system. This unit was affixed to the same pole as the bilge pump. Radon and YSI data were collected at 10-minute and 10-second (s) intervals, respectively.

Electrical resistivity (continuous resistivity profiles; CRP) was run in conjunction with surface-water radon mapping where possible. A Supersting R8/IP unit (Advanced Geosciences, Inc.) and a 100-m-long cable with a 10-m electrode spacing was used to collect an electrical-resistivity image to a depth of approximately $25 \mathrm{~m}$. The Supersting R8/IP injects a current of up to 2 amps and power of 200 watts. In CRP mode, the Supersting unit can simultaneously measure eight channels while injecting a current at a rate of 1 to $3 \mathrm{~s}$. The 11-electrode cable was set up in a streaming dipole-dipole array. The first two electrodes produced the current (current electrodes) and the remaining nine measured the resulting voltage potential (potential electrodes). The boat towed the cable, suspended by pool floats, along the water surface, and apparent resistivity with eight simultaneous measurement points, each at a different apparent depth (0 to $25 \mathrm{~m}$ ), was collected. Data were geo-referenced by streaming time and position from a Wide Area Augmentation System (WAAS)-enabled Lowrance LMS-480 Global Positioning System (GPS) device directly into the AGI Supersting unit. An additional WAAS-enable Garmin GPS was used to collect position for the radon and YSI data.

\section{Time-Series Radon Sites}

To obtain an estimate of groundwater discharge (advection) rates at a single location, two time-series radon sites were established. The time-series radon system consisted of a RAD7 unit measuring surface-water radon and a RAD7 unit measuring atmospheric radon. The setup was identical to that of the surface-water mapping efforts except that, since only one RAD7 was used, the sampling interval was set at $30 \mathrm{~min}$. Surface-water elevation, salinity, and temperature were either measured in situ at the site or downloaded from nearby meteorological/oceanographic stations. Advective fluxes were inferred from radon time-series data using a ${ }^{222} \mathrm{Rn}$ water-column mass-balance model (Corbett, and others 2000; Dulaiova and others, 2005; Cable, and others 2006; Burnett and others, 2007). The model balances the radon watercolumn inventory with known sources (advective porewater influx, radioactive production) and sinks (atmospheric evasion, tidal mixing, and radioactive decay) of ${ }^{222} \mathrm{Rn}$, as defined by equation 1 and as depicted in figure 6 (modified from Burnett and others, 2007).

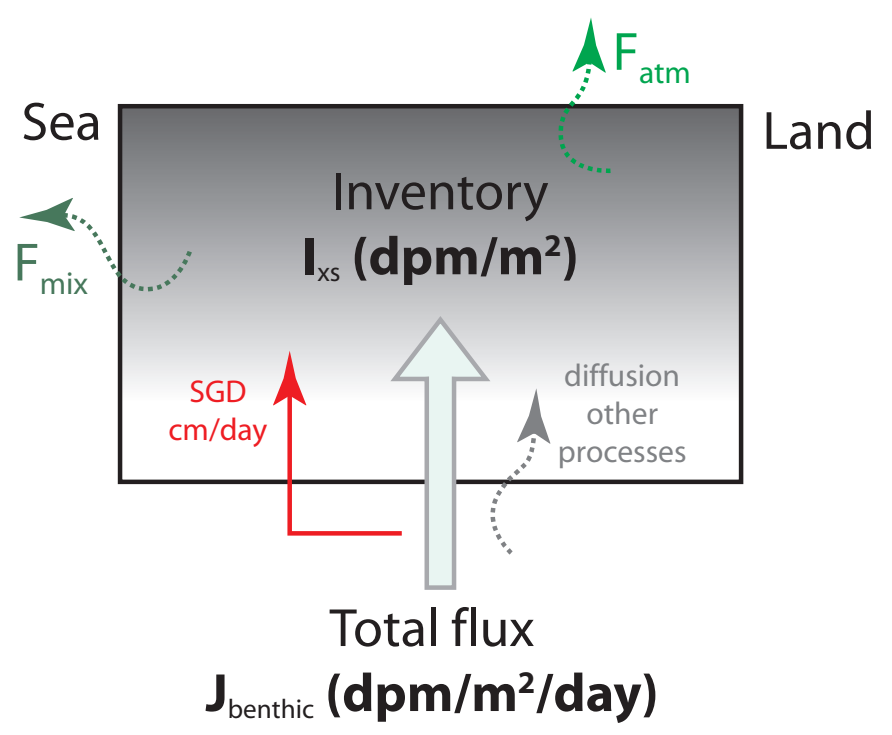

Figure 6. Conceptual box model of radon inflows and losses to a coastal water body where inventory $\left(I_{X S}\right)$ is measured over time, and total flux $\left(J_{\text {benthic }}\right)$ is calculated by adjusting for atmospheric $\left(F_{\text {atm }}\right)$ and mixing $\left(F_{m i x}\right)$ losses (modified from Burnett and others, 2007). [SGD, submarine groundwater discharge; $\mathrm{dpm} / \mathrm{m}^{3}$, disintegrations per minute per cubic meter; $\mathrm{cm}$, centimeter]

$$
J_{\text {benthic }}-F_{a t m} \pm F_{\text {mix }}=\lambda z\left(A_{R n}-A_{R a}\right)=\lambda I_{x s},
$$

where

$J_{\text {benthic }}$ is benthic flux of ${ }^{222} \mathrm{Rn}\left(\mathrm{dpm} / \mathrm{m}^{2} /\right.$ day $)$,

$\lambda$ is the decay coefficient $(0.181 \mathrm{~d}-1)$,

$A_{R} a$ and $A_{R n}$ are the water-column activity of radium-226 $\left({ }^{226} \mathrm{Ra}\right)$ and ${ }^{222} \mathrm{Rn}\left(\mathrm{dpm} / \mathrm{m}^{3}\right)$, respectively,

$z$ is water depth (m),

$F_{\text {atm }}$ is the atmospheric flux of radon (dpm $/ \mathrm{m}^{2} /$ day),

$F_{\text {mix }}$ is the flux associated with tidal mixing and/or unidirectional surface-water flow $\left(\mathrm{dpm} / \mathrm{m}^{2} /\right.$ day $)$, and

$I_{x s}$ is excess-radon inventory $\left(\mathrm{dpm} / \mathrm{m}^{2}\right)$.

The following text highlights how the mass-balance model is used to convert time-series radon measurements into advective-fluid fluxes (Dulaiova and others, 2005). The first step involves computing the excess ${ }^{222} \mathrm{Rn}$ water-column inventory. The $\mathrm{Rad} 7$ measures ${ }^{222} \mathrm{Rn}$ activity $\left(\mathrm{dpm} / \mathrm{m}^{3}\right.$ air $)$ as radon in air; this activity is multiplied by the Ostwald temperature concentration factor ( $K_{O}$; unitless) (eq. 2$)$ to get radon in water:

$$
K_{O}=0.105+0.405^{-0.0502^{*} T w}
$$

where $T_{w}$ is water temperature $\left({ }^{\circ} \mathrm{C}\right)$. 
The radon-in-water value is then corrected for in situ production via the decay of ${ }^{226} \mathrm{Ra}\left(A_{R a}\right)$ to obtain excess ${ }^{222} \mathrm{Rn}$. This study assumed a ${ }^{226} \mathrm{Ra}$ value of $200 \mathrm{dpm} / \mathrm{m}^{3}$ (Swarzenski and others, 2008). The excess ${ }^{222} \mathrm{Rn}$ is multiplied by the water-column thickness (water depth) to obtain the excess radon inventory $\left(\mathrm{dpm} / \mathrm{m}^{2}\right)$. Radon flux $\left(\mathrm{dpm} / \mathrm{m}^{2} / \mathrm{hr}\right)$ is calculated by taking the change in excess-radon inventories over time and then multiplying by ${ }^{222} \mathrm{Rn}$-decay constant.

Next, the different source and sink terms are computed from measured parameters. For example, the atmospheric flux $\left(F_{\text {atm }} ; \mathrm{dpm} / \mathrm{m}^{2} / \mathrm{hr}\right)$ is calculated by gradient in radon across the water-air interface interface:

$$
F_{\text {atm }}=\left[R n_{\text {water }}-\left(K_{O} * R n_{\text {air }}\right)\right] * K(600),
$$

where

$$
\begin{aligned}
R n_{\text {water }} & \text { is radon activity in water }\left(\mathrm{dpm} / \mathrm{m}^{3}\right), \\
R n_{\text {air }} & \text { is radon activity in air }\left(\mathrm{dpm} / \mathrm{m}^{3}\right), \\
K_{O} & \text { is the Ostwalt temperature-concentration } \\
& \text { coefficient (unitless), and } \\
K(600) & \text { is the vertical diffusive coefficient }(\mathrm{m} / \mathrm{hr}) .
\end{aligned}
$$

The vertical diffusive coefficient is computed from the empirical relation defined by MacIntyre and others (1995):

$$
K(600)=0.45 u_{10}^{1.6}(S c / 600)^{-2 / 3},
$$

where

$$
u_{10} \begin{aligned}
& \text { is wind speed measured } 10 \mathrm{~m} \text { above land surface } \\
& (\mathrm{m} / \mathrm{hr}) \text { and }
\end{aligned}
$$

$S c$ is the Schmidt number (ratio of kinematic viscosity and molecular diffusion; $\mathrm{m} / \mathrm{hr}$ ).

Flood/ebb tidal corrections $\left(F_{m i x}\right)$ were calculated by subtracting adjacent water-level measurements and noting if the difference was positive (flood tide) or negative (ebb tide). Net radon flux $\left(\mathrm{dpm} / \mathrm{m}^{2} / \mathrm{hr}\right)$ was calculated by adding radon flux and atmospheric flux and then subtracting losses to the system from flood/ebb tides. Mixing losses were calculated when the net radon fluxes were negative; otherwise, these values were zero because it was assumed that radon was being added to the system and not lost due to atmospheric evasion or mixed with lower radon flood/ebb tidal waters. Total benthic radon flux $\left(J_{\text {benthic }} ; \mathrm{dpm} / \mathrm{m}^{2} / \mathrm{hr}\right.$ ) was then calculated by subtracting mixing losses from net radon flux. To obtain specific discharge $(q ; \mathrm{cm} / \mathrm{d})$ from time-series radon measurements, the total radon flux $\left(\mathrm{dpm} / \mathrm{m}^{2} / \mathrm{hr}\right)$ was divided by the mean porewater-radon activity $\left(\mathrm{dpm} / \mathrm{m}^{3}\right)$ :

$$
q=\left(J_{\text {benthic }} * 100 * 24\right) / R n_{p w},
$$

where $R n_{p w}$ is porewater-radon activity $\left(\mathrm{dpm} / \mathrm{m}^{3}\right)$.

\section{Results and Interpretation}

\section{Continuous Radon Mapping}

Radon-222 was mapped throughout the Caloosahatchee River from near the mouth (Little Shell Island) upstream to structure S-79. Integrated surface-water activities ranged from 1-2 dpm/L (disintegrations per minute per liter) near the mouth of the river to $12.7 \mathrm{dpm} / \mathrm{L}$ along the narrow river section east of I-75 (fig. 7). These data indicate that the tidal reach of the river can be broken into three segments: (1) from the mouth of the river up to the US-41 (Tamiami) bridges (area 1), (2) from the US-41 bridges to the I-75 overpass (area 2), and (3) from the I-75 overpass to structure S-79 (area 3$)$. Area 1 has low radon activity (1-5 dpm/L) and is indicative of a well-flushed coastal water mass (Fanning and others, 1982). The upper, narrow region of the river (area 3) has an increase in radon activity $(8-13 \mathrm{dpm} / \mathrm{L})$ that most likely results from groundwater discharge since the only source of ${ }^{222} \mathrm{Rn}$ is from the subsurface. Area 2 is the transition zone between the well-flushed area 1 and the groundwaterinfluenced area 3, as indicated by radon activities (5-8 $\mathrm{dpm} / \mathrm{L}$ ). The slightly elevated radon activities in area 2 could originate from groundwater discharge or from simple mixing between areas 1 and 2 . Without adequate knowledge of mixing rates or residence time of the surface water, no conclusion can be made based on the data presented as to whether area 2 has active groundwater discharge.

To assess the validity that the upper reach (area 3 ) of the river is influenced by greater groundwater inflows than the lower reach (area 1), an activity per volume of river was calculated. The average of all ${ }^{222} \mathrm{Rn}$ activity $(\mathrm{dpm} / \mathrm{L})$ along with the area $\left(\mathrm{km}^{2}\right)$ of the river in each of the three sections was computed, and a uniform average water depth of $5 \mathrm{~m}$ for the tidal reach of the Caloosahatchee was used in the volume calculation. The results (fig. 8) indicate that there is a significant increase in activity per volume in area $3\left(0.13 \mathrm{dpm} / \mathrm{L} / \mathrm{km}^{3}\right)$ over area $2\left(0.0047 \mathrm{dpm} / \mathrm{L} / \mathrm{km}^{3}\right)$ and area $1\left(0.00031 \mathrm{dpm} / \mathrm{L} / \mathrm{km}^{3}\right)$. These results indicate a greater groundwater component in the upper reach compared with the lower sections of the river.

Radon was collected during similar tidal (incoming) conditions (fig. 9) allowing for direct comparisons from day to day. Slight tidal-height amplitude changes over the week were minor $(<12 \mathrm{~cm})$ and should not impact the magnitude of radon observed. In addition to the radon, surface salinity and temperature were measured also. Salinity shows a gradual freshening from the mouth of the river to structure S-79 (fig. 10). The salinity was most likely higher than normal for the river because there were no releases from structure S-79 during the study period (previous release date was March 3, 2009; fig. 3) and very low rainfall had occurred during 2009 prior to data collection (total 2009 rainfall of 1.97 inches at S-79; fig. 3). A significant portion of the low-salinity water in 


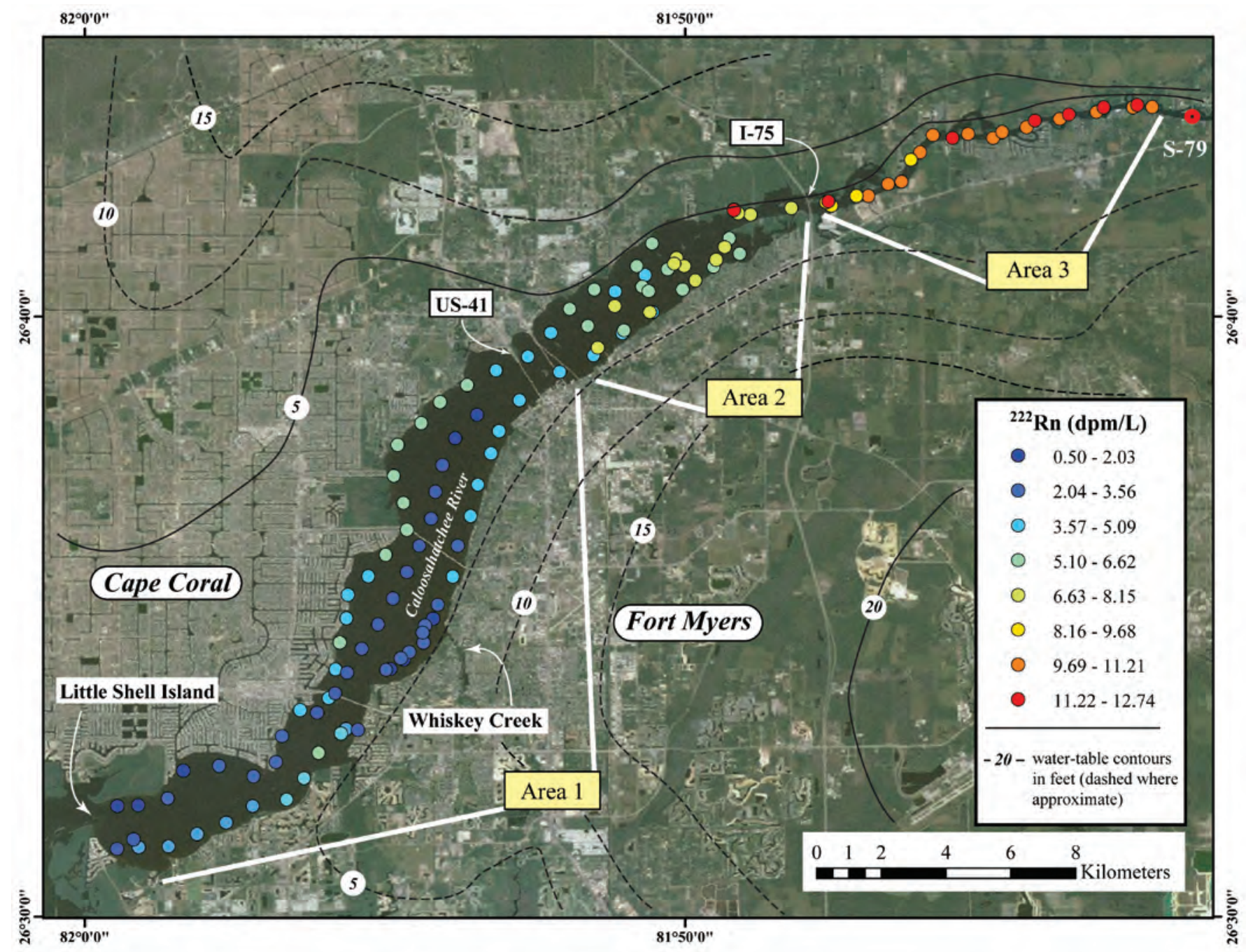

Figure 7. Continuous ${ }^{222} \mathrm{Rn}$ map showing an increase in radon activity from near the mouth of the river up to the $\mathrm{S}-79$ structure. Radon-222 activities (in disintegrations per minute per liter, dpm/L) are at 10-min intervals. Segments of the river are divided into areas 1,2 , and 3 based on ${ }^{222} \mathrm{Rn}$ activities in surface water. Water-table elevations (in feet) are shown on map (modified from Krulikas and Giese, 1995).

the upper section of the river likely originates from groundwater baseflow. Surface-water temperature was on average $\sim 26{ }^{\circ} \mathrm{C}$. However, near the Florida Power \& Light Company electric powerplant (near I-75), temperature was observed to increase to near $33^{\circ} \mathrm{C}$ (fig. 11).

Water-table contours for the surficial aquifer (fig. 7; Krulikas and Giese, 1995) generally support the zonation indicated by the surface-water radon maps. Data on the water-table map represent a 10-year average from 1982 to 1991 , so some caution is warranted in direct comparison between radon and water-table data. The closely spaced contours along the shore of the river east of I-75 indicate a steep hydraulic gradient capable of driving groundwater discharge into the river. Within area 2, the hydraulic gradient shallows, subsequently decreasing the possibility of groundwater discharge. As mentioned, the radon data do not support or refute discharge within area 2. One inconsistency between the water-table potentiometric map and radon map occurs within area 3. Low-radon activity in area 1 is inconsistent with the inferred positions of the 5-, 10-, and 15-ft contours along the southern shoreline within this area. Assuming that the contours are representative of water-table elevations, then one would expect much higher radon activity along the Fort Myers shoreline transect relative to the Cape Coral shoreline and midchannel transects. Since this is not the case, the inferred placement of the 5-, 10-, and 15-ft contours is apparently incorrect, and the contour data should be refined by additional observations. 


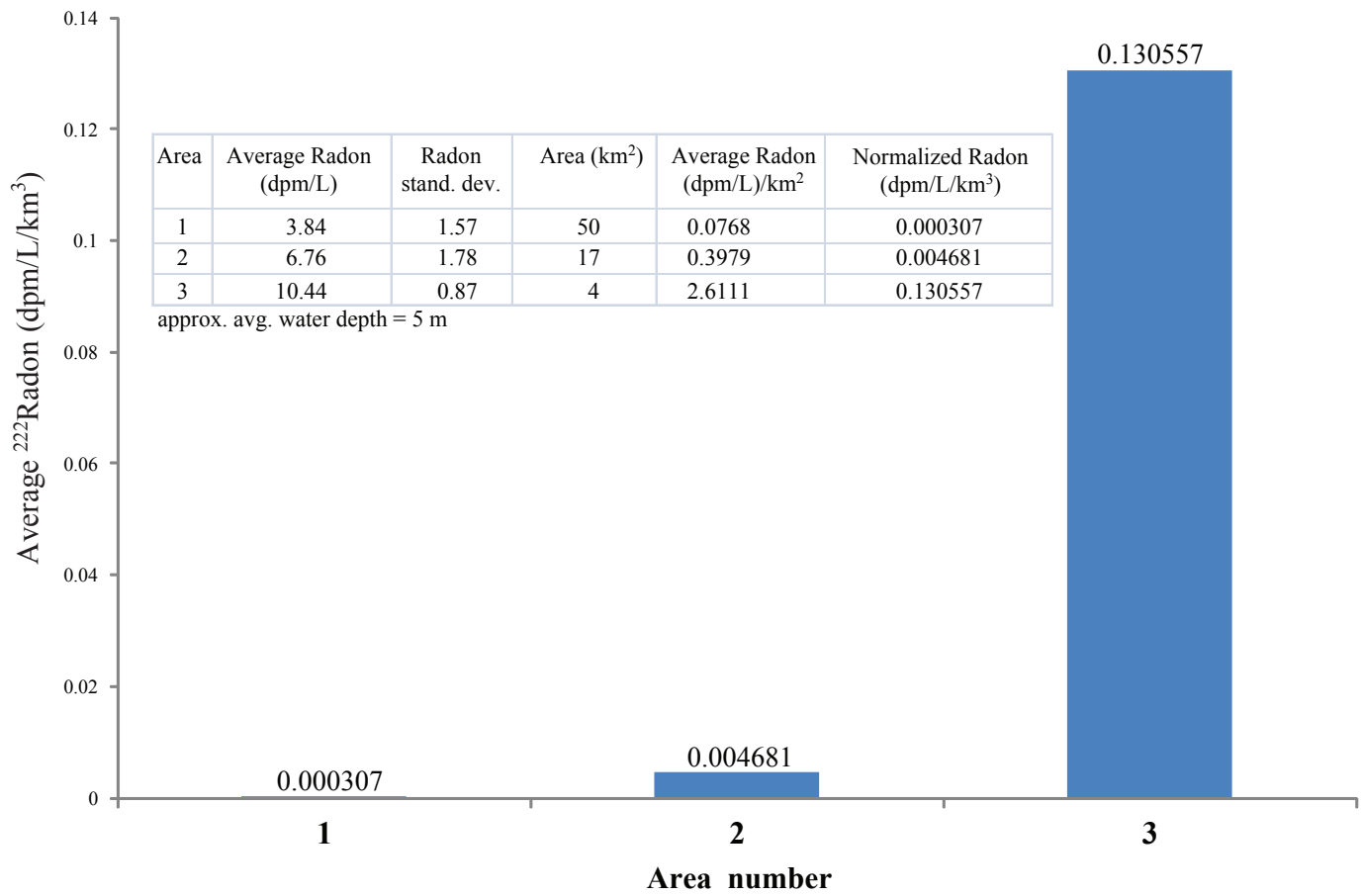

Figure 8. Normalized radon per volume of river (disintegrations per minute per liter per cubic kilometer, $\mathrm{dpm} / \mathrm{L} / \mathrm{km}^{3}$ ) for the three river areas that were divided on the basis of surface-water ${ }^{222} \mathrm{Rn}$ activity in figure 7 .

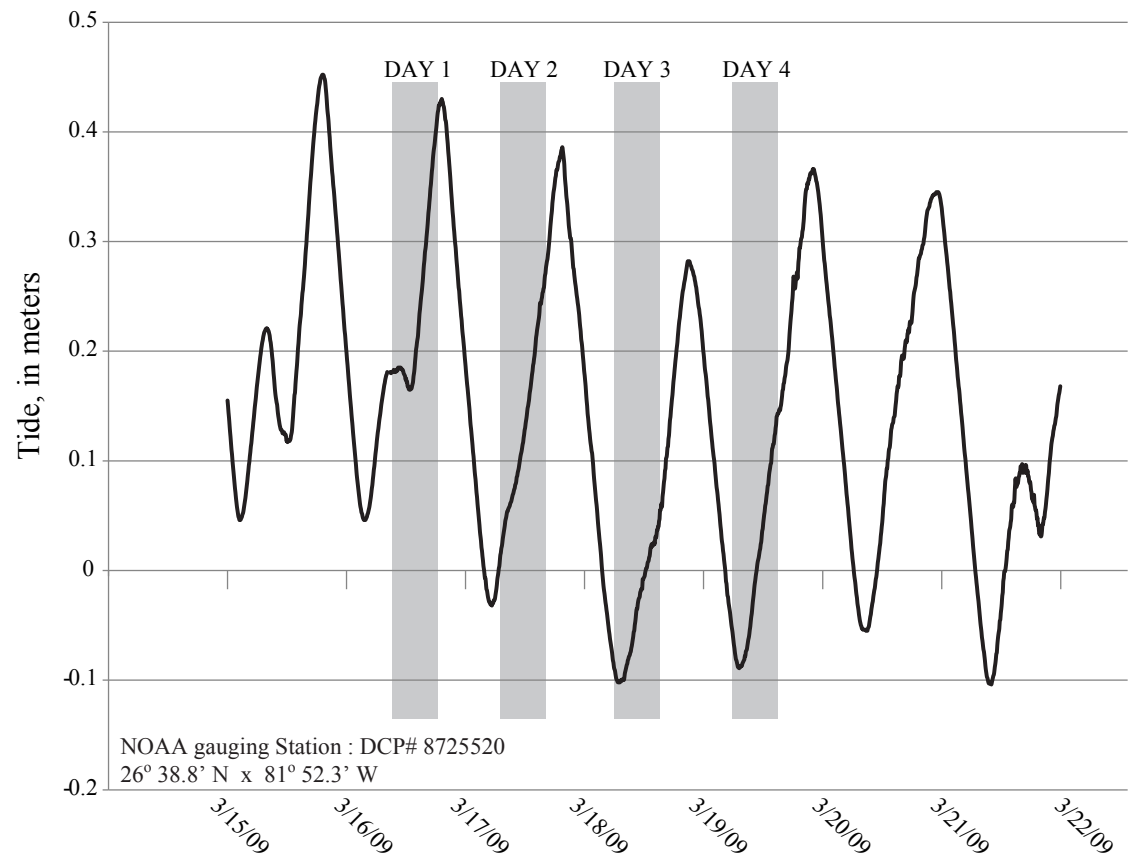

Figure 9. Tidal signal collected by the NOAA gaging station located beneath the US-41 (Edison) bridge on the Caloosahatchee River. 


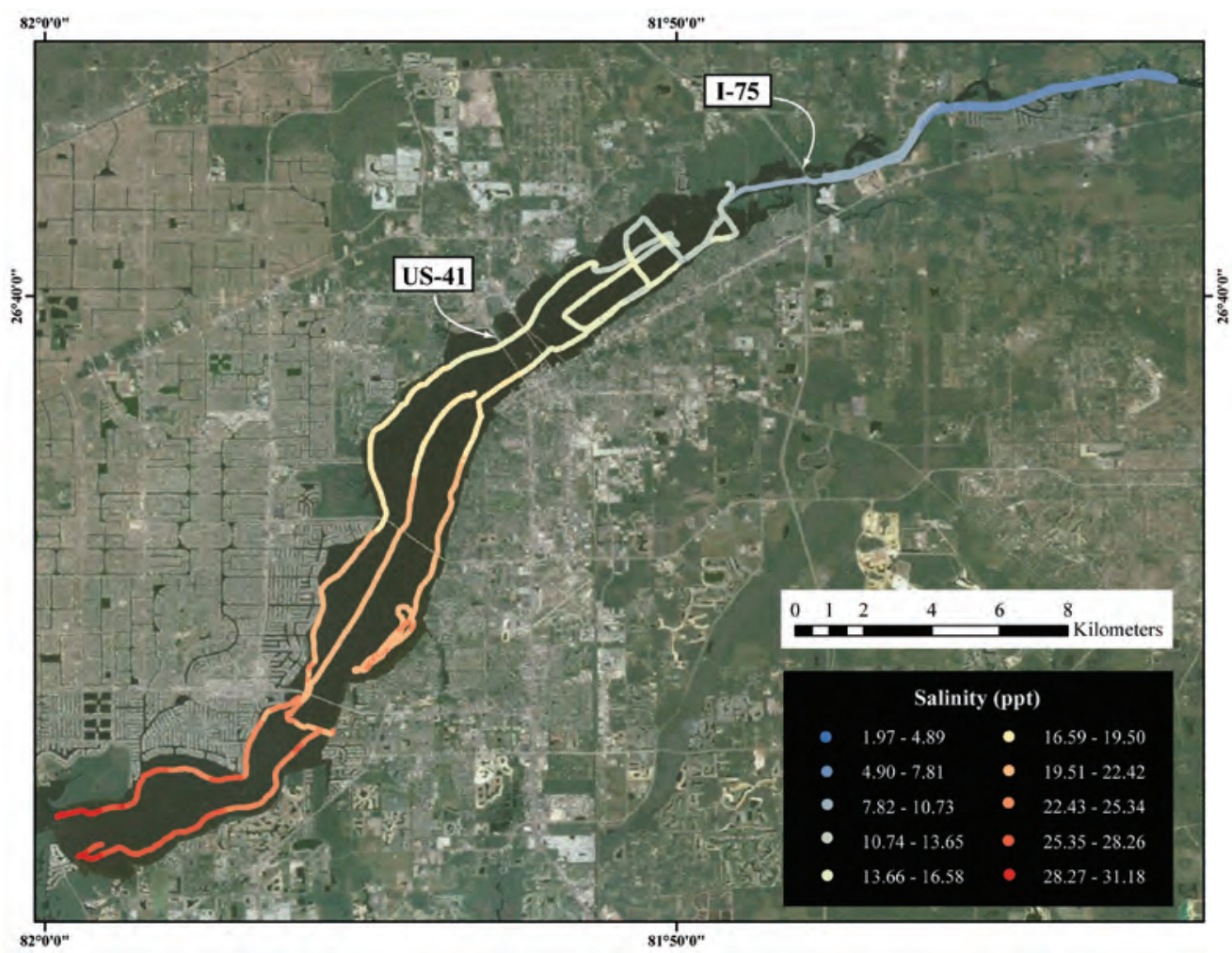

Figure 10. Continuous surface-water salinity values collected during radon and resistivity surveys.

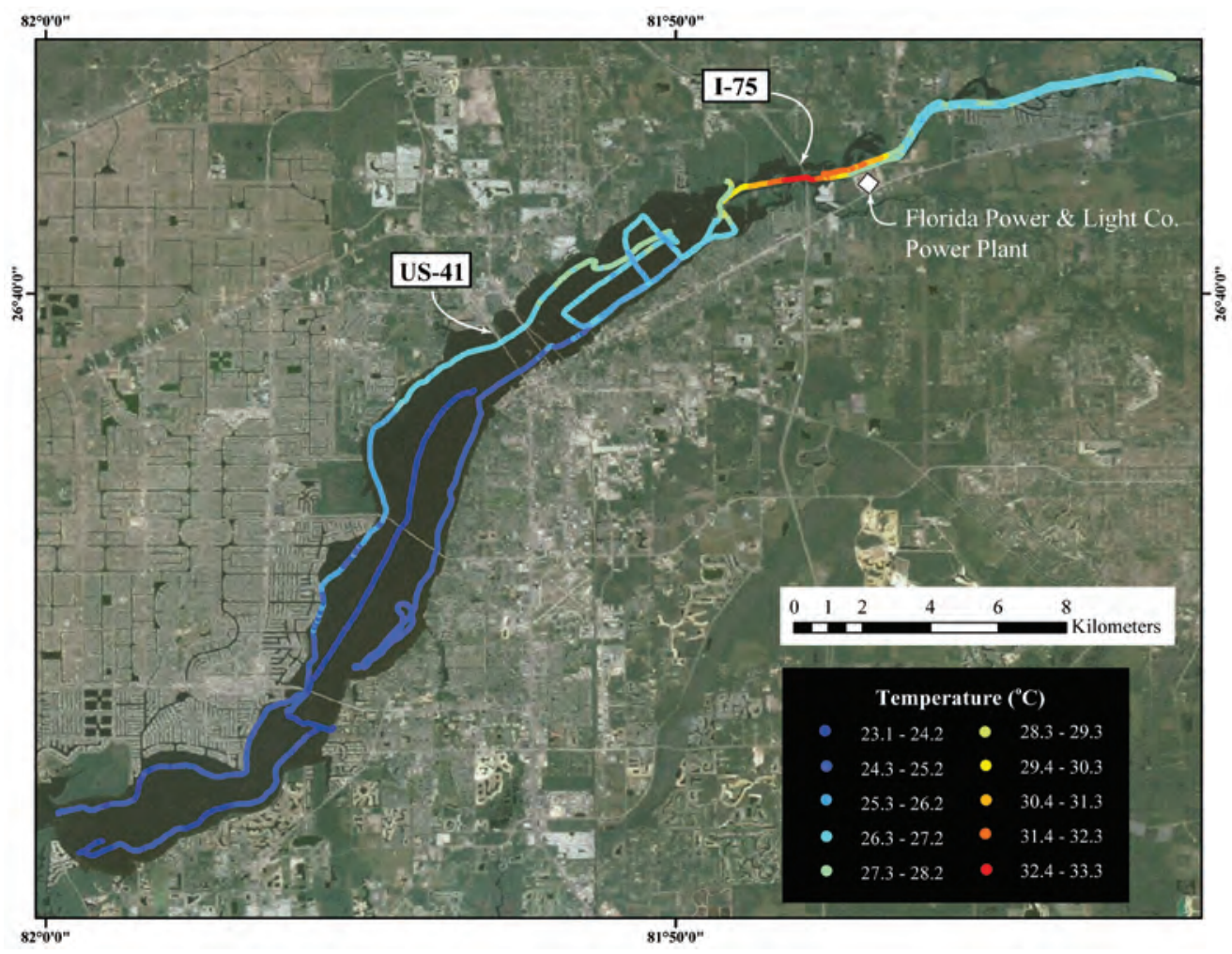

Figure 11. Continuous surface-water temperature values collected during radon and resistivity surveys. Note the increase in temperature near the Florida Power \& Light Co. powerplant, located east of I-75. 


\section{Time-Series Radon and Groundwater Discharge Estimates}

Two time-series radon-monitoring sites were established to provide initial estimates of dry-season groundwater discharge into the Caloosahatchee River system (fig. 2). The first site was located at Whiskey Creek, a tributary of the Caloosahatchee River, and was monitored from March 15 to 19,2009 . The second site was located near structure S-79 and was monitored for $8 \mathrm{hr}$ on March 19, 2009. The S-79 site was located on the undeveloped portion of the southern shore $<1 \mathrm{~km}$ west of S-79. Four RAD7s (same setup as for the mapping surveys) were used to measure radon at 10-min intervals over the day-long experiment. In addition, a piezometer was used along the shore to measure porewater radon and salinity at various depths to obtain a porewater profile as well as to measure radon and salinity at a specified depth over the span of the experiment. Advective fluxes were calculated based on formulas presented in the Methods of Investigation section.

\section{Whiskey Creek Site}

The Whiskey Creek site was established on a private dock and the instruments run for 4 consecutive days (March 15-19, 2009; figs. 12 and 13). A single RAD7 was used at the dock to measure surface-water radon and a second RAD7 was used to measure radon in air. The air-monitor data were used for both the S-79 and dock calculations. Tidal data were collected from a NOAA tidal station (DCP\# 8725520). Radon activities at the dock were slightly elevated when compared to just offshore from the Whiskey Creek entrance. Values in the river were approximately $4 \mathrm{dpm} / \mathrm{L}$ (fig. 7), and values during the week at the time-series site ranged from 8 to $22 \mathrm{dpm} / \mathrm{L}$, after omitting the radon spike at 0800 on March 16 (fig. 13A). Radon concentration was inversely correlated with tide, indicating that groundwater was being added to the system when the hydraulic gradient was the greatest (low tide). The net radon-flux and advective-flux estimates are not strongly correlated to tide (fig. $13 B, C$ ), however there is a subtle tidal response during the lowest low tides on March 18

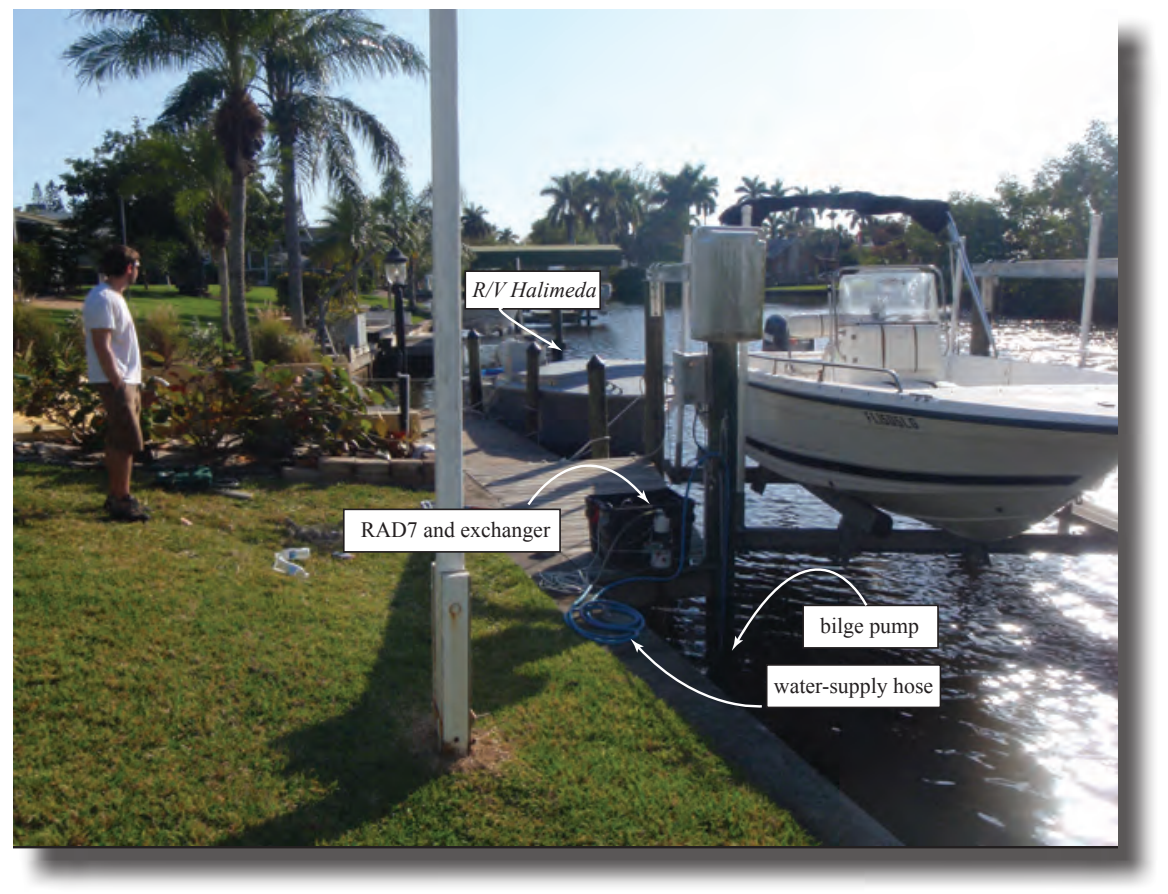

Figure 12. Time-series radon equipment at the Whiskey Creek site. Note black box (foreground) on dock containing RAD7 radon monitors and air-water exchanger. Also note modified shoreline at Whiskey Creek site compared to S-79 time-series site in figure 14 

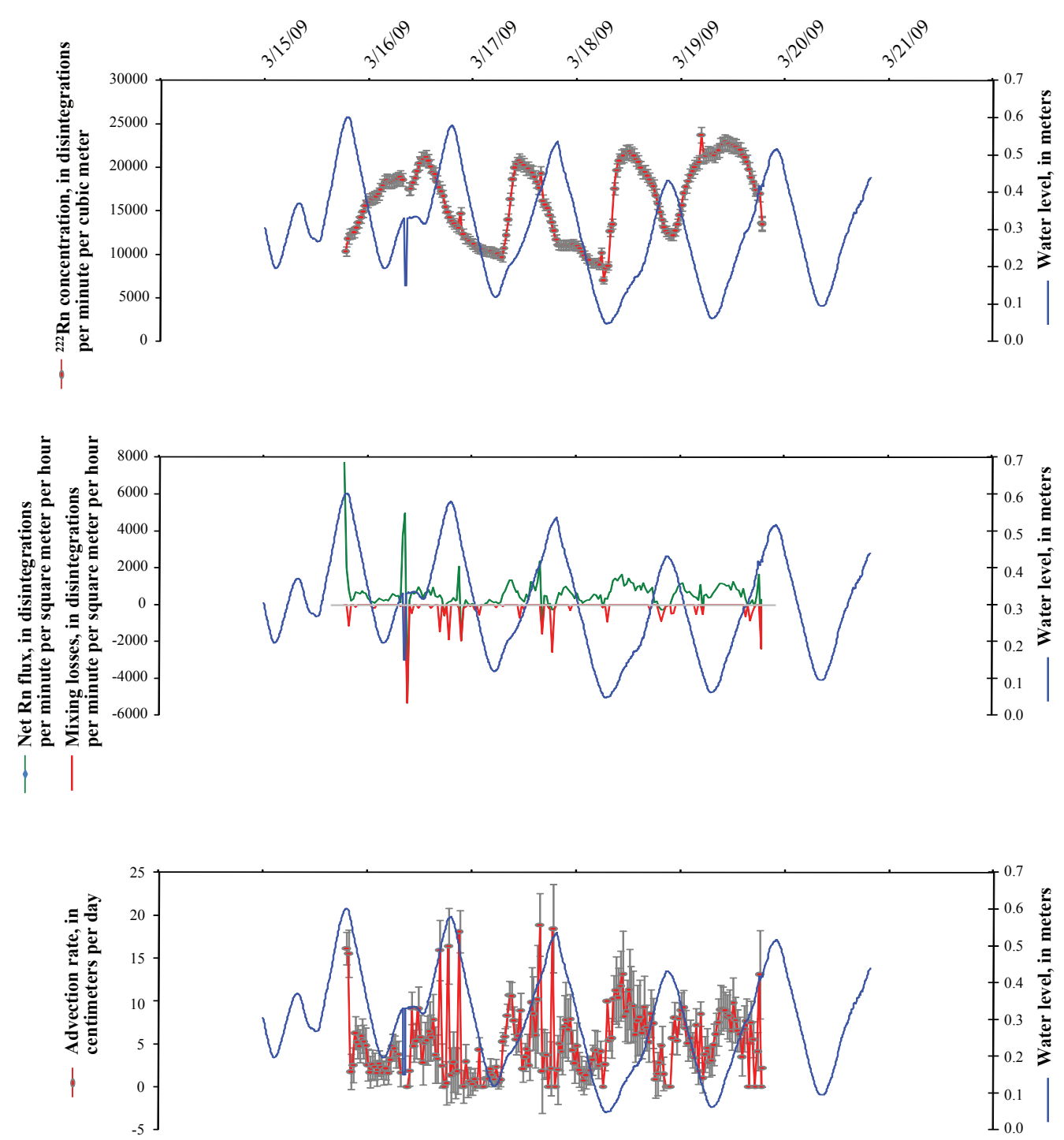

Figure 13. Graphs of (A) ${ }^{222} \mathrm{Rn}$ in water, (B) ${ }^{222} \mathrm{Rn}$ net flux, and (C) advective flux at the Whiskey Creek time-series site, March 15-19, 2009. Changing water level indicates a semi-diurnal tidal cycle during the 4-day-long experiment. Gray line in B is the zero reference line to help identify flux as net positive or net negative.

and 19, 2009. Radon concentration and advective flux do not correspond similarly to tide. This is primarily due to the fact that conservative mixing estimates used in the calculations smooth out the values for advection. The corrections for atmospheric and tidal mixing (tides and reflux of surface water into the subsurface) can result in the smoothing of the calculated advective fluxes. The average advective flux calculated for the dock site was $5.7 \pm 6.4 \mathrm{~cm} / \mathrm{d}$ using an average porewater ${ }^{222} \mathrm{Rn}$ concentration of $3,000 \mathrm{dpm} / \mathrm{L}$.

\section{Lock and Dam Site (S-79)}

The ${ }^{222} \mathrm{Rn}$ time-series results from the S-79 site (fig. 14) show that groundwater discharge is occurring in the upper reach of Caloosahatchee River and is modulated by tides (fig. 15A). Rn-222 activity increased steadily until 1100 (maximum activity $88,000 \mathrm{dpm} \mathrm{m}^{-3}$ ) and declined exponentially to an activity of $17,900 \mathrm{dpm} \mathrm{m}^{-3}$ toward the end of the survey. The peak in ${ }^{222} \mathrm{Rn}$ activity occurred within $80 \mathrm{~min}$ 


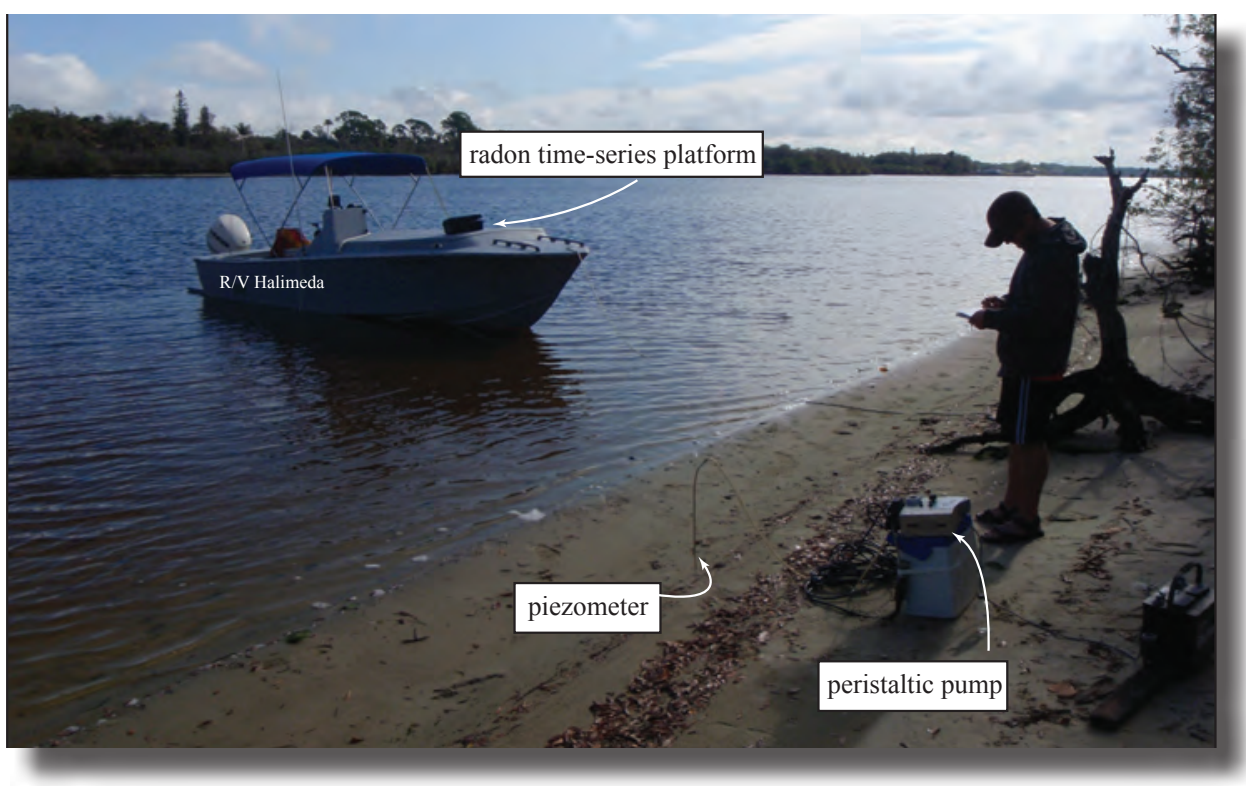

Figure 14. The S-79 time-series site shows the R/V Halimeda used as the platform for collecting radon and surface-water data, and the piezometer and pump used to collect porewater and radon samples (foreground).
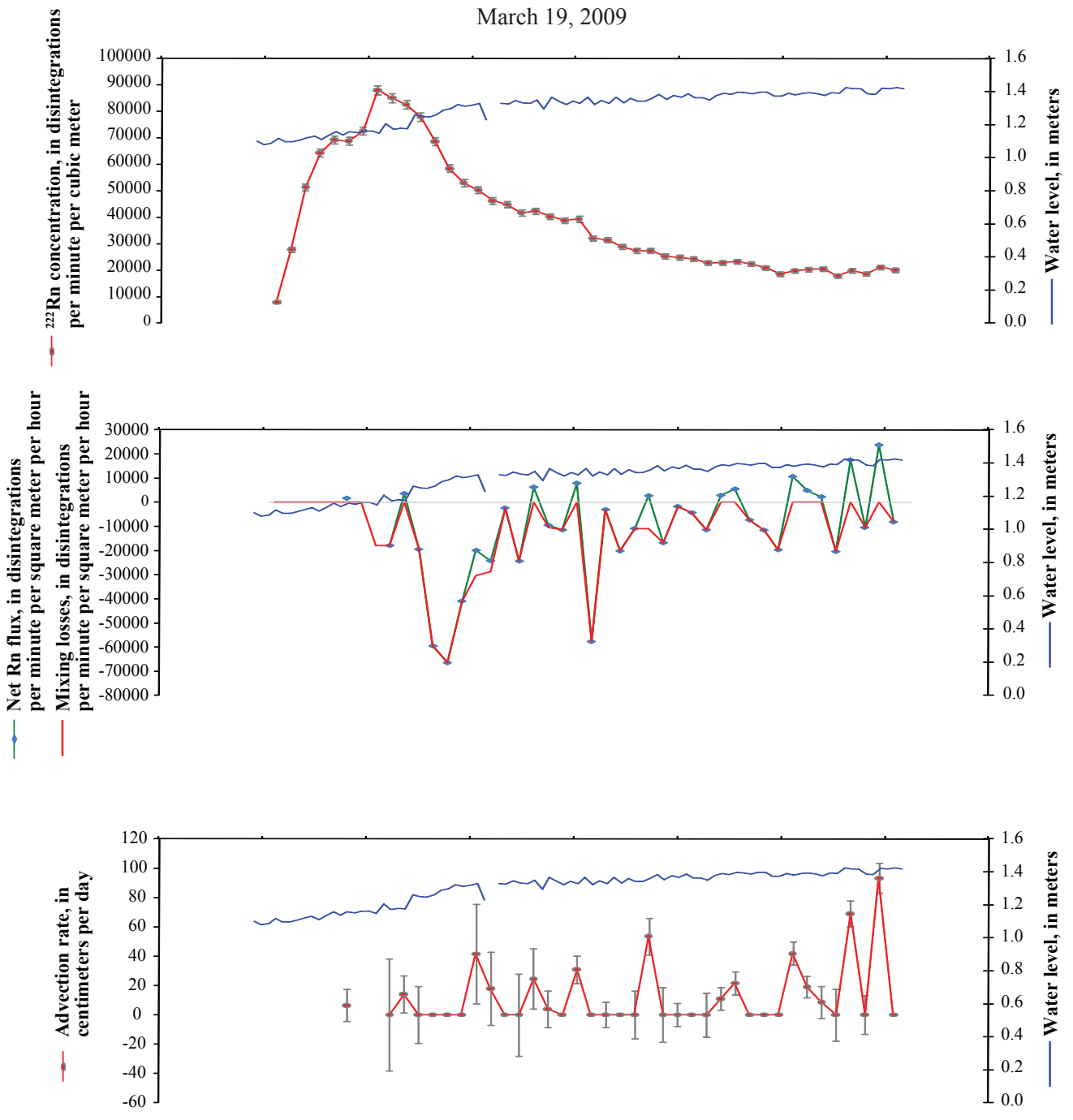

Figure 15. Graphs of $(A)^{222} \mathrm{Rn}$ in water, $(B){ }^{222}$ Rn net flux, and (C) advective flux at the $S-79$ time-series site on March 19, 2009. Changing water level indicates a rising (flood) tide. Gray line is the zero reference line to help identify flux as net positive or net negative. 
of the survey, which is beyond the typical equilibration time ( $\sim 30 \mathrm{~min})$ for ${ }^{222} \mathrm{Rn}$ measured using the RAD7. This indicates that the high radon activity is not an artifact of the equilibration process and is the result of groundwater discharge. The subsequent decline in radon following the peak indicates that groundwater become less important as the survey progressed. Figure $15 B$ shows both net radon flux and mixing losses. The maximum radon activity and inferred groundwater discharge occur during the later stages of the low tide (onset of flood tide), which is consistent with tidally modulated groundwater discharge. Ataie-Ashtiani and others (2001) showed that groundwater discharge was out of phase with tides (high discharge during low-tide). In addition to the tidal forcing, the enhanced discharge may also have resulted from a short but intense storm that produced $0.5 \mathrm{in}$. of rain during the early hours of March 19, 2009 (fig. 3). Percolation of recent precipitation through the unsaturated zone and subsequent mounding of the water table may have enhanced the hydraulic gradient between the surficial aquifer and the river, allowing enhanced groundwater discharge.

Additional support for the tide-influenced groundwater discharge comes from porewater time-series sampling conducted simultaneously with the surface-water survey at the S-79 site (table 1; fig. 14). The porewater salinity and radon profiles (fig. 16) show a well-defined gradient with depth. Salinity in the surface water at the time-series site averaged 8 parts per thousand (ppt) and decreased to $2.8 \mathrm{ppt}$ at $55 \mathrm{~cm}$ below the sediment-water interface. Radon activity increased with depth from an average of $38.5 \pm 22 \mathrm{dpm} / \mathrm{L}$ in surface water to $9,590 \pm 608 \mathrm{dpm} / \mathrm{L}$ at $55 \mathrm{~cm}$. The timeseries radon data collected from a depth of $55 \mathrm{~cm}$ over $6 \mathrm{hr}$ slowly decreased from $9,590 \mathrm{dpm} / \mathrm{L}$ to $7,570 \mathrm{dpm} / \mathrm{L}$. Salinity showed an inverse pattern by increasing over the $6 \mathrm{hr}$ from $2.7 \mathrm{ppt}$ to $3.75 \mathrm{ppt}$. The increase in salinity indicates that incoming tidal waters were being pushed into the surficial sediments, displacing or pushing back the higher radon and lower salinity porewaters, resulting in the cessation of the advective-flow component shown in figure $15 \mathrm{~A}$.

Under the assumption that these data reflect tidally modulated groundwater discharge, the advective component can be separated into their respective tidal stages (low-tide discharge and high-tide discharge). Based on the 10-min time-averaged radon flux of $32,798 \mathrm{dpm} / \mathrm{m}^{2} / \mathrm{hr}$ and the porewater radon activity of $6,085 \mathrm{dpm} / \mathrm{L}$, the low-tide discharge estimate averages $129.5 \pm 205.2 \mathrm{~cm} / \mathrm{d}$. Since a complete tidal cycle was not monitored, the upper end of groundwater discharge was used. During high tide, groundwater discharge averages $14.5 \pm 25.9$ $\mathrm{cm} / \mathrm{d}$, assuming an average radon flux of $3,680 \mathrm{dpm} / \mathrm{m}^{2} / \mathrm{hr}$ and porewater radon activity of $6,085 \mathrm{dpm} / \mathrm{L}$. In comparison, the average flux for all data was $66.7 \pm 151 \mathrm{~cm} / \mathrm{d}(\mathrm{n}=44)$.

Table 1. Porewater ${ }^{222} \mathrm{Rn}$, salinity, and temperature collected at two sites during the time-series experiment near lock and dam structure S-79.

$\left[\mathrm{cm}\right.$, centimeter; ${ }^{\circ} \mathrm{C}$, celsius; ppt, parts per thousand; dpm/L, disintegrations per minute per liter

\begin{tabular}{|c|c|c|c|c|c|c|c|c|c|c|}
\hline Site & Date/Time & $\begin{array}{l}\text { North } \\
\text { latitude }\end{array}$ & $\begin{array}{c}\text { West } \\
\text { longitude }\end{array}$ & $\begin{array}{l}\text { Porewater } \\
\text { depth (cm) }\end{array}$ & $\begin{array}{l}\text { Temperature } \\
\left({ }^{\circ} \mathrm{C}\right)\end{array}$ & $\underset{\text { (ppt) }}{\text { Salinity }}$ & $\begin{array}{l}\text { Radon } \\
\text { (pCi/L) }\end{array}$ & Error & $\begin{array}{l}\text { Radon } \\
\text { (dpm/L) }\end{array}$ & Error \\
\hline \multicolumn{11}{|c|}{ Individual porewater samples along Caloosahatchee River } \\
\hline PW-1-Cal & $3 / 18 / 200915: 23$ & 26.7241 & -81.7067 & 30 & 23.61 & 4.59 & $1,020.00$ & 70.40 & $2,264.40$ & 156.29 \\
\hline PW-2-Cal & 3/18/2009 16:07 & 26.7157 & -81.7510 & 30 & 23.97 & 6.22 & 167.00 & 12.40 & 370.74 & 27.53 \\
\hline PW-2-S79 & 3/19/2009 10:05 & 26.7241 & -81.7067 & 25 & 21.15 & 6.04 & $1,060.00$ & 104.00 & $2,353.20$ & 230.88 \\
\hline PW-3-S79 & $3 / 19 / 200910: 16$ & 26.7241 & -81.7067 & 35 & 21.56 & 5.00 & $2,010.00$ & 175.00 & $4,462.20$ & 388.50 \\
\hline PW-4-S79 & $3 / 19 / 200910: 38$ & 26.7241 & -81.7067 & 55 & 21.78 & 2.70 & $4,320.00$ & 274.00 & $9,590.40$ & 608.28 \\
\hline PW-5-S79 & $3 / 19 / 200912: 38$ & 26.7241 & -81.7067 & 55 & 21.65 & 3.57 & $3,760.00$ & 124.00 & $8,347.20$ & 275.28 \\
\hline
\end{tabular}




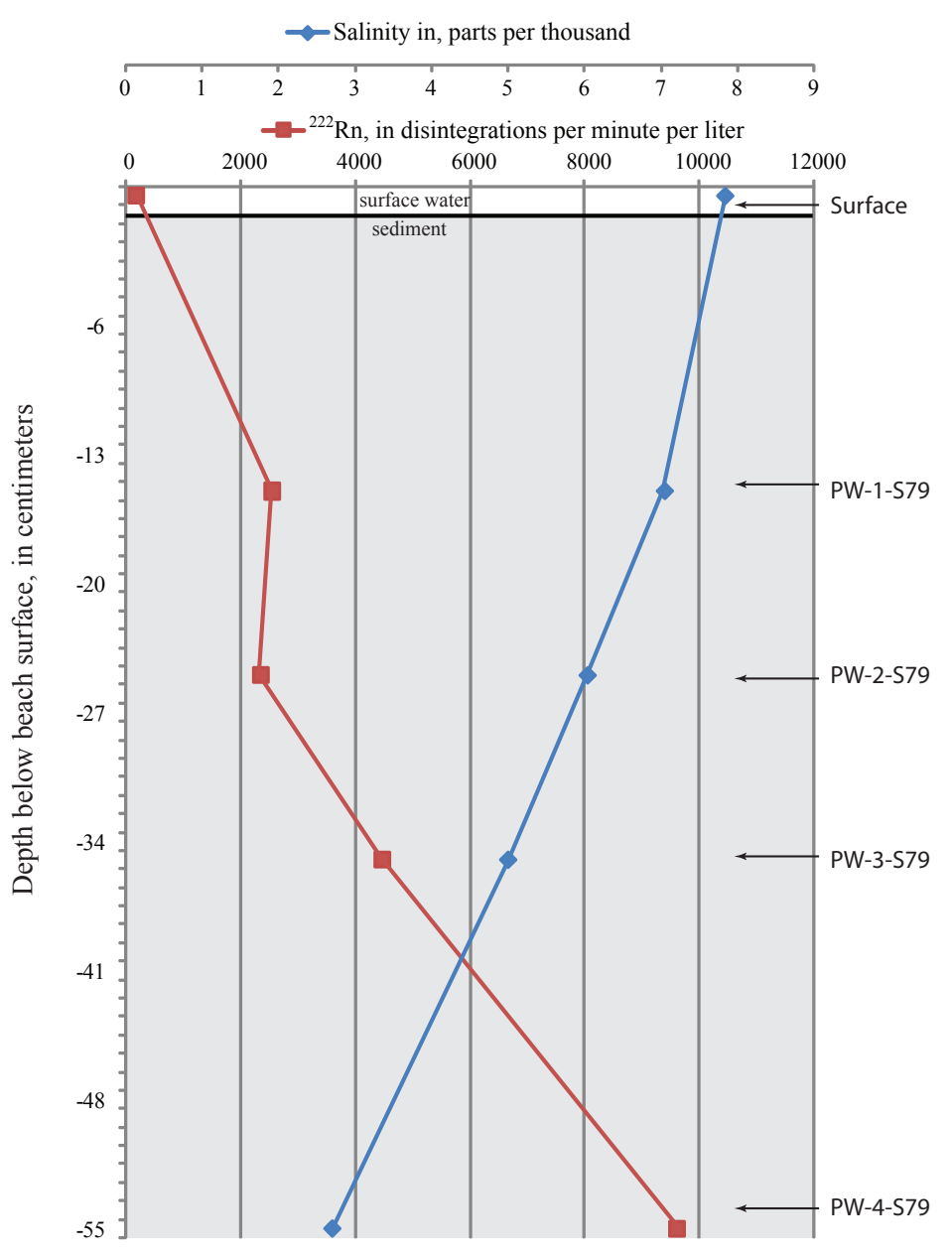

Figure 16. Vertical profile of surface-water and porewater salinity and ${ }^{222} \mathrm{Rn}$ collected at the S-79 time-series site. Blue line shows salinity decreasing with depth and red line shows increasing ${ }^{222} \mathrm{Rn}$ activity with depth.

\section{Comparison with other Florida Sites}

The mass-balance estimates of advective fluxes for both the S-79 and Whiskey Creek sites correspond well to other data from elsewhere in Florida (table 2). Table 2 compares advective fluxes at various locations that were derived from three methods: direct measurement by seepage meters, radon mass-balance, and radium mass-balance derivations. The flux estimates for groundwater entering coastal areas in Florida show that low hydraulic-gradient regions produce groundwater flows in the range of 0 to 49 with an average of approximately $13 \mathrm{~cm} / \mathrm{d}$.

\section{Continuous Resistivity Profiling Surveys}

Electrical resistivity is a useful tool for mapping potential sources and pathways for groundwater (fresh or saline) flow but is not a quantitative method for directly measuring groundwater discharge. CRP measures an "apparent" resistivity that includes both the pore-fluid and lithologic resistivity. A priori knowledge of either the geology or groundwater-fluid conductivity is beneficial in the interpretation of the CRP profiles. Interpretation of resistivity in this study was based on generalized geologic and hydrologic maps because sediment/rock cores or monitoring wells do not exist for use in ground-truthing.

Approximately 100 line-km of electrical resistivity were collected during the study period. The CRP lines are divided into 52 line segments (fig. 17 and appendix). CRP tracklines were run simultaneously with radon surveys and covered both the southern and northern shorelines from near the mouth of the river (Little Shell Island) to the lock and dam (S-79; fig. 17). A CRP track along the river axis was also run; however, weather conditions had deteriorated on March 18 such that wind caused a moderate chop on the river and resulted in errors within the resistivity data. Noticeable errors in CRP lines CAL09 and CAL11 (appendix) are marked with "poor data" labels and error-prone zones are grayed out. Weather conditions during the first 2 survey days were near perfect for resistivity and radon data collection. 
Table 2. Variability in advective fluxes and methods by which fluxes are derived for different sites within Florida.

$[\mathrm{cm} / \mathrm{d}$, centimeter per day

\begin{tabular}{|c|c|c|}
\hline Florida location & Reference & $\begin{array}{l}\text { Advective flux, average } \\
\text { or range }(\mathrm{cm} / \mathrm{d})\end{array}$ \\
\hline Florida Bay ${ }^{1}$ & Shinn and others, 2002 & 0.1 to 6 \\
\hline Florida Bay ${ }^{3}$ & Corbett and others, 2000 & 0.3 to 2.5 \\
\hline Florida Bay $^{3}$ & Chanton and others, 2003 & 0 to 15 \\
\hline Florida Bay ${ }^{3}$ & Swarzenski and others, 2008 & $12.5 \pm 11.8$ \\
\hline Biscayne Bay ${ }^{2}$ & Reich (unpublished data, 2004) & $23.2 \pm 19.6$ \\
\hline Hendry County (C-3 canal $)^{1}$ & Cunningham and others, 2001 & $<1$ to 49 \\
\hline Panhandle (FSUML) ${ }^{2}$ & Burnett and Dulaiova, 2003 & 6 to 13 \\
\hline Panhandle (FSUML) ${ }^{3}$ & Burnett and Dulaiova, 2003 & $13 \pm 9$ \\
\hline Panhandle (FSUML) ${ }^{4}$ & Burnett and Dulaiova, 2003 & 11.2 to 21 \\
\hline Loxahatchee River ${ }^{4}$ & Swarzenski and others, 2006 & 2 to 7 \\
\hline Loxahatchee River $^{2}$ & Swarzenski and others, 2006 & 1.7 \\
\hline Indian River Lagoon ${ }^{1}$ & Cable and others, 2006 & 1 to 12 \\
\hline Indian River Lagoon ${ }^{3}$ & Martin and others, 2007 & $16 \pm 43$ \\
\hline Indian River Lagoon $^{1}$ & Martin and others, 2007 & 1.6 to 18.4 \\
\hline Indian River Lagoon ${ }^{3}$ & Smith and others, 2008 & 2.5 to 24 \\
\hline Caloosahatchee River ${ }^{3}$ & this study (upper river reach) & $12.3 \pm 21.9$ \\
\hline Caloosahatchee River ${ }^{3}$ & this study (lower river reach) & $5.7 \pm 6.4$ \\
\hline \multicolumn{3}{|l|}{${ }^{1}$ Seepage meter (Lee type, bag) } \\
\hline \multicolumn{3}{|l|}{${ }^{2}$ Seepage meter (autonomous) } \\
\hline \multicolumn{3}{|l|}{${ }^{3}$ Radon mass balance } \\
\hline${ }^{4}$ Radium mass balance & & \\
\hline
\end{tabular}

The resistivity profiles are shown in the appendix. The resistivity survey was divided into two sections: lower section, west of I-75, and upper section, east of I-75. These two sections have two different log-linear scales. Normalizing the profiles to a common-scale range allows direct comparison between profiles. The lower river section resistivity values were lower due to seawater influence (seawater resistivity $=0.20 \mathrm{ohm}$-meters, ohm-m). The upper river was influenced by both shallow and deep, fresh to brackish water. Resistivity along the upper tidal reach of the river ranged from 0.20 to $50 \mathrm{ohm}-\mathrm{m}$, whereas the middle and lower sections of the river had resistivity values that ranged from 0.20 to $15 \mathrm{ohm}-\mathrm{m}$. The highest resistivity for the area south of the US-41 bridges was typically $<10 \mathrm{ohm}-\mathrm{m}$.
The geology of the Caloosahatchee River valley is complex, and lithologies vary over the $45-\mathrm{km}$ stretch of river surveyed in this study, making interpretation of resistivity challenging (fig. 4). Resistivity profiles (appendix) exhibit a variety of possible interpretations that range from artifacts to geological variability. Buried cables or pipelines or bridge pilings can be recorded by the CRP system. CAL04 6000$8000(5660 \mathrm{~m})$ and CAL06_8000-10000 (7420 m) contain examples of bridge-piling artifacts. CAL08_200-2000 $(\sim 800 \mathrm{~m})$ contains an example of a buried pipeline or cable or, at least, is coincidental with a buried cable as marked on a USGS topographic map. 


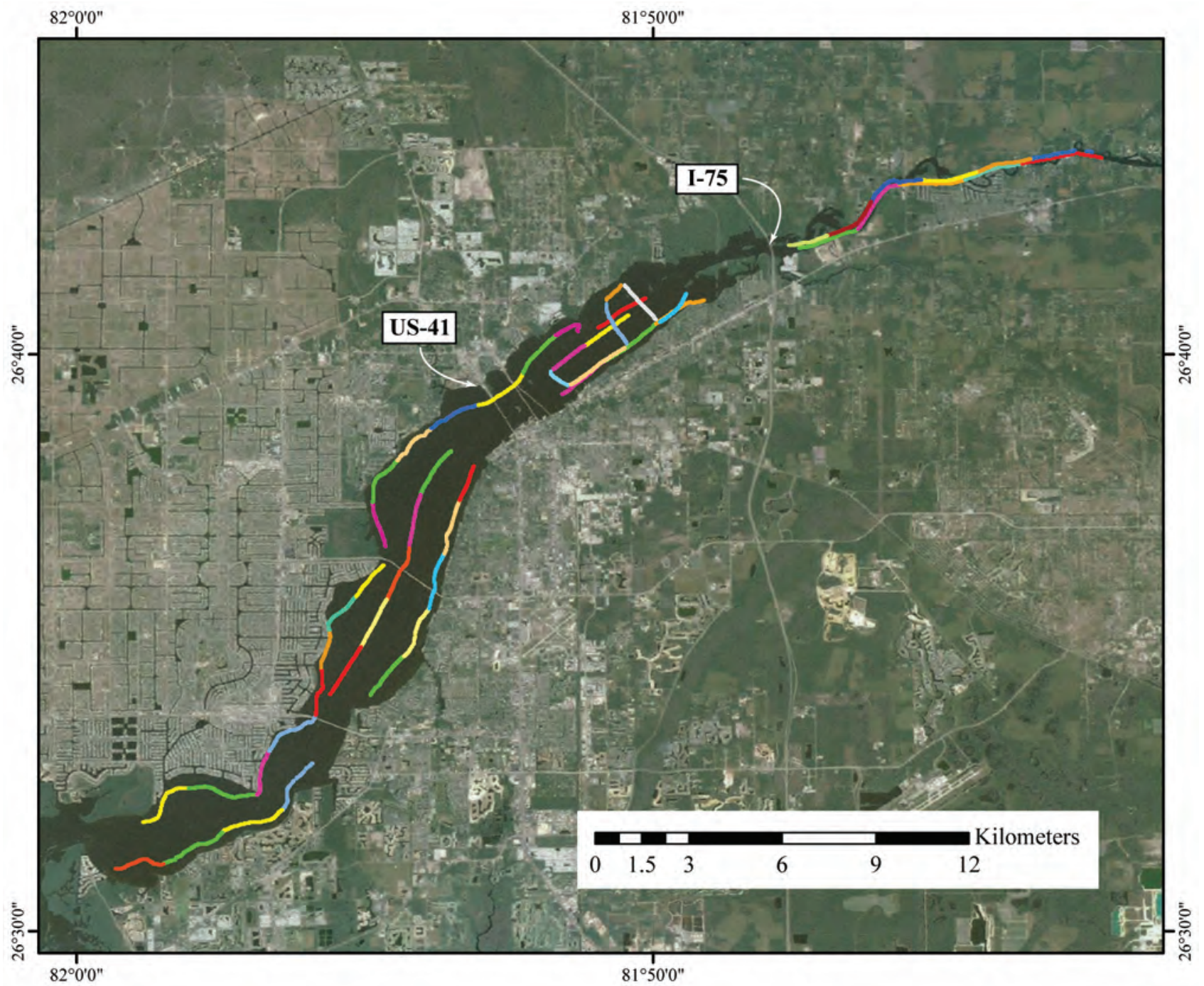

Figure 17. Individual segments of continuous resistivity profiles (CRP) collected in the Caloosahatchee River. Each CRP segment corresponds to its respective resistivity profile shown in the appendix

Uniform geology, whereby marine water penetrates uniform quartz-sand units of the TQsu, is present in CRP profiles CAL01_2000-4000 and CAL06_200-2000. These two examples are error free and are consistent across the profile. There are, however, resistivity profiles that demonstrate geologic processes that may represent paleokarst activity, such as subsidence and sinkhole activity. An example of a possible sinkhole feature can be seen in line CAL06 2000-4000 ( 1,800-2,200 m). CAL06 20004000 shows high-resistivity material $(\sim 6 \mathrm{ohm}-\mathrm{m})$ flanking a moderately resistive material $(1.5 \mathrm{ohm}-\mathrm{m})$ in what could be considered the "throat" of a sinkhole. This example has been seen in CRP images collected in freshwater lakes near Orlando, FL, that are known to have formed from sinkhole activity (Reich and others, 2009). Other examples of possible solution/sinkhole activity can be seen in lines CAL06_4000$6000(\sim 3,330 \mathrm{~m})$, CAL04 10000-11400 (9,550-9,700 m), and CAL05 8000-10000 ( 8, $\overline{7} 45 \mathrm{~m})$.
Shore-normal CRP tracklines were conducted on March 17 in the area between the US-41 and I-75 bridges. In addition to possible sinkhole or subsidence features, sags or swales in resistivity profiles running shore-normal may represent buried paleochannels. Three profiles contain areas where moderately resistive material ( $\sim 1.5$ to $2 \mathrm{ohm}-\mathrm{m})$ depresses into higher-resistivity material ( $\sim 7 \mathrm{ohm}-\mathrm{m})$. CRP lines CAL08_3441-3992 ( 3,500 m), CAL08 6913-8744 $(\sim 6,450 \mathrm{~m})$, and CAL08 10057-11816 ( 9,200 $\mathrm{m}$ and $\sim 9,360 \mathrm{~m}$ ) exhibit a possible buried paleoriver-channel shape. High-resolution seismic-reflection profiles along similar transects would aid in the correct identification of the paleoriver channels since there would be a distinctive erosional and infilling pattern.

There is also a response in the CRP data that potentially could be a result of fresh groundwater. This response is limited to the narrow section of the Caloosahatchee River from I-75 to site S-79. The higher resistivity in the CRP data 
above the I-75 overpass is indicative of increased occurrence of freshwater in the subsurface, because freshwater has a much higher resistivity than seawater. The presence of fresher groundwater is the reason the span in the log-linear scale on the resistivity is much greater $(0.2-50 \mathrm{ohm}-\mathrm{m})$ than the section of the river west of I-75 $(0.2-15 \mathrm{ohm}-\mathrm{m})$. CRP line CAL03_8000-10600, the line closest to site S-79, shows the highest-resistivity value ( $48 \mathrm{ohm}-\mathrm{m})$ of any CRP data collected during this survey. It is known from this study that shallow-porewater-salinity values at the time-series site were $\sim 4$ ppt (fig. 16 and table 1). The CAL03_8000-10600 profile shows a higher shallow subsurface resistivity along the undeveloped and slightly higher elevation land near the end of the profile (9,220 to 9,929 m). This could be indicative of fresh groundwater underlying the river. It would be ideal to establish a shore-normal resistivity transect and porewater sampling effort along this stretch of the river to confirm the presence of the fresher, subsurface groundwater.

\section{Summary}

Combined radon and electrical-resistivity data from this study demonstrate the variability in the geologic controls on groundwater discharge to the Caloosahatchee River. The increase in surface-water radon upstream from I-75 indicates that groundwater is discharging into the narrow section of the river at a higher rate than is observed in the wider section of the river south of I-75. An increase in resistivity values in the subsurface confirms that fresher groundwater underlies the upper part of the Caloosahatchee River and is coincident with increased ${ }^{222} \mathrm{Rn}$ activities.

Groundwater-discharge rates were estimated using a mass-balance approach on data from time-series radonmonitoring stations at two locations along the river. The monitor at Whiskey Creek (southern region of the river) was run for 4 consecutive days. The average estimated groundwater advective flux for this site was $5.7 \pm 6.4 \mathrm{~cm} / \mathrm{d}$. The second monitoring time-series station was established near the S-79 structure, but was only run for $8 \mathrm{hr}$. Surface-radon concentrations were extremely high at the beginning of the experiment $(\sim 88 \mathrm{dpm} / \mathrm{L})$ and were attributed to enhanced groundwater discharge caused by a storm that produced $\sim 0.5 \mathrm{in}$. of rain recorded at the S-79 structure. The radon activity decreased at an exponential rate during the 8-hr study period and ended near background values observed 3 days prior to the measurements. The advective flux estimated for the upstream site was $66.7 \pm 151 \mathrm{~cm} / \mathrm{d}$. This value is most likely an overestimate due to the high radon values at the beginning of the study and the short duration of the study. A more conservative estimate would be to average the smaller peaks that ranged from 0 to $93 \mathrm{~cm} / \mathrm{d}$ (average $=12.3 \pm 21.9 \mathrm{~cm} / \mathrm{d}$ ).

\section{Suggestions for Further Study}

This study was intended to provide the SFWMD with a map of potential groundwater-discharge sites and an initial estimate of groundwater advective fluxes. To fully grasp the SGD contribution of water to the tidal reach of the Caloosahatchee River, several ( $\sim 4)$ time-series radon monitors could be installed within the three areas of the river identified in figure 7. This study took place during the dry season, and therefore the values derived here are at the lower estimates of SGD to the river. Advective fluxes of $\sim 13 \mathrm{~cm} / \mathrm{d}$ (upper) and $5 \mathrm{~cm} / \mathrm{d}$ (lower) are good estimates and are values that are acceptable and relevant, considering the hydrologicregime differences between the two sites. Future work could include establishing two time-series monitor sites in area 1 , one in area 2, and one in area 3. The 8-hr radon time-series near the S-79 site gave an important first-order approximation of groundwater advective fluxes, but a longer time-series (4-5 days) effort would result in a better estimate over tidal cycles and lock and dam releases. Additional porewater-radon measurements at all time-series sites would be critical to advective-flux calculations. Land-based (stationary) resistivity measurements would also benefit the understanding of advective fluxes. Though resistivity is not quantitative, as shown in this report, it can lend credence to understanding the hydrogeology that drives groundwater flow. Land-based resistivity can be collected hourly and can image the impact of tidal or meteorological events on the movement of groundwater (Swarzenski and others, 2007; Simonds and others, 2008). Although time-consuming, collecting cores in the river and porewater chemistry (salinity) would help ground-truth the resistivity data.

\section{Acknowledgments}

The author thanks Kathy Haunert and Detong Sun of the South Florida Water Management District for funding this study (project agreement number 4500031361), and to Eduardo Patino of the U.S. Geological Survey for initiating this investigation. The author thanks Peter Swarzenski for access to electrical-resistivity and radon equipment. Special gratitude is extended to Patricia Smiley for granting the USGS use of her boat dock. This report was greatly enhanced by the diligent reviews of Michael Byrne, Christopher Smith, Barbara Lidz, and John Watson. 


\section{References Cited}

Ataie-Ashtiani, B.A., Volker, R.E., Lockington, D.A., 2001, Tidal effects on groundwater dynamics in unconfined aquifers: Hydrological Processes, v. 15, no. 4, p. 655-669.

Boggess, D.H., Missimer, T.M., and O’Donnell, T.H., 1981, Hydrogeologic sections through Lee County and adjacent areas of Hendry and Collier Counties, Florida: U.S. Geological Survey Open-File Report 81-638, 1 p.

Burnett, W.C., Bokuniewicz, H., Huettel, M., Moore, W.S., and Taniguchi, M., 2003, Groundwater and pore water inputs to the coastal zone: Biogeochemistry, v. 66, p. 3-33.

Burnett, W.C., and Dulaiova, H., 2003, Estimating the dynamics of groundwater input into the coast zone via continuous radon-222 measurements: Environmental Radioactivity, v. 69 , p. 21-35.

Burnett W.C., Kim, G., and Lane-Smith, D., 2001, A continuous radon monitor for use in coastal ocean waters: Journal of Radioanalytical and Nuclear Chemistry, v. 249, p. 167-172.

Burnett, W.C., Santos, I.R., Weinstein, Y., Swarzenski, P.W., and Herut, B., 2007, Remaining uncertainties in the use of Rn-222 as a quantitative tracer of submarine groundwater discharge: Proceedings of Symposium HS101 at IUGG2007, Perugia, Italy, July 2007, 10 p.

Cable, J.E., Martin, J.B., and Jaeger, J., 2006, Exonerating Bernoulli? On evaluating the physical and biological processes affecting marine seepage meter measurements: Limnology and Oceanography, v. 4, p. 172-183.

Chanton, J.P., Burnett, W.P., Dulaiova, H., Corbett, D.R., and Taniguchi, M., 2003, Seepage rate variability in Florida Bay driven by Atlantic tidal height: Biogeochemistry, v. 66, p. 187-202.

Corbett, D.R., Dillon, K., Burnett, W., and Chanton, J., 2000, Estimating the groundwater contribution into Florida Bay via natural tracers, ${ }^{222} \mathrm{Rn}$ and $\mathrm{CH} 4$ : Limnology and Oceanography, v. 45 , no. 7 , p. 1546-1557.

Cunningham, K.J., Locker, S.D., Hine, A.C., Bukry, D., Barron, J.A., and Guertin, L.A., 2001, Surface-geophysical characterization of ground-water systems of the Caloosahatchee River basin, southern Florida: U.S. Geological Survey WaterResources Investigation Report 2001-4084, 76 p.

Doering, P.H., and Chamberlain, R.H., 1999, Water quality and source of freshwater discharge to the Caloosahatchee Estuary, Florida: Journal of the American Water Resources Association, v. 35, no. 4, p. 793-806.
Dulaiova, H., and Burnett, W.C., 2006, Radon loss across the water-air interface (Gulf of Thailand) estimated from ${ }^{222} \mathrm{Rn} /{ }^{224} \mathrm{Ra}$ : Geophysical Research Letters, v. 33, L05606, doi: 10.1029/2005GL025023.

Dulaiova, H., Burnett, W.C., and Lane-Smith, D., 2005, A multi-detector continuous monitor for assessment of ${ }^{222} \mathrm{Rn}$ in the coastal ocean: Journal of Radioanalytical and Nuclear Chemistry, v. 263, no. 2, p. 361-365.

Fanning, K.A., Breland, J.A., and Byrne, R.H., 1982, Radium-226 and Radon-222 in the coastal waters of west Florida: High concentrations and atmospheric degassing: Science, v. 215, no. 4533, p. 667-670.

Fernandez, M., Jr., Marot, M.E., and Holmes, C.W., 1999, Reconnaissance of chemical and physical characteristics of selected bottom sediments of the Caloosahatchee River and estuary, tributaries, and contiguous bays, Lee County, Florida, July 20-30, 1998: U.S. Geological Survey OpenFile Report 99-226, 32 p., 88-page app., 7 pls.

Flaig, E.G., and Capece, J., 1998, Water use and runoff in the Caloosahatchee watershed, in Proceedings of the Charlotte Harbor Public Conference and Technical Symposium, Technical Report No. 98-02: Charlotte Harbor National Estuary Program, Punta Gorda, FL, p. 73-80.

Krulikas, R.K., and Giese, G.L., 1995, Recharge to the surficial aquifer system in Lee and Hendry Counties, Florida: U.S. Geological Survey Water-Resources Investigations Report 95-4003, 26 p., plus pls.

MacIntyre, S., Wanninkhof, R., and Chanton, J.P., 1995, Trace gas exchange across the air-sea interface in freshwater and coastal marine environments, in Matson, P.A., and Harris, R.C., eds., Biogenic trace gases: measuring emissions from soil and water: Malden, MA, Blackwell Science, p. 52- 97.

Martin, J.B., Cable, J.E, Smith, C.G., Roy, M., and Cherrier, J., 2007, Magnitudes of submarine groundwater discharge from marine and terrestrial sources: Indian River Lagoon, Florida: Water Resources Research, v. 43, W05440, doi:10.1029/2006WR005266.

Missimer, T., 1978, The Tamiami Formation-Hawthorn Formation contact in southwest Florida: Florida Scientist, v. 41 , no. 1 , p. 31-39.

Missimer, T., 1999, Sequence stratigraphy of the late Miocene-early Pliocene Peace River Formation, southwestern Florida: Gulf Coast Association of Geological Societies Transactions, v. 49, p. 358-368.

Ortiz, A.G., 2008, Potentiometric surface of the upper Floridan aquifer, west-central Florida, May 2008: U.S. Geological Survey Scientific Investigations Map 3057, 1 p. 
Reich, C.D., Shinn, E.A., Hickey, T.D., and Tihansky, A.B., 2002, Tidal and meteorological influences on shallow marine groundwater flow in the Upper Florida Keys, in Porter, J.W., and Porter, K.G., eds., The Everglades, Florida Bay and coral reefs of the Florida Keys: An Ecosystem source-book, Boca Raton, FL, CRC Press, p. 659-676.

Reich, C., Flocks, J., and Davis, J., 2009, Geologic investigation of sinkhole lakes near Orlando, FL using seismic reflection and direct current resistivity: Southeast Geological Society of America Annual Meeting, March 12-13, 2009, Abstracts with Programs, v. 41, no. 1, p. 17.

Reich, C.D., Swarzenski, P.W., Greenwood, W.J., and Wiese, D.S., 2008, Investigation of coastal hydrogeology utilizing geophysical and geochemical tools along the Broward County coast, Florida. U.S. Geological Survey Open-File Report 2008-1364, 21 p., plus 3 apps.

Scott, T.M., 2001, Geologic map of Florida: Florida Geological Survey Open-File Report 80, 30 p.

South Florida Water Management District (SFWMD), 2009, Caloosahatchee River Watershed Protection Plan: Brooksville, 279 p., plus apps.

Shinn, E.A., Reich, C.D., and Hickey, T.D., 2002, Seepage meters and Bernoulli's revenge: Estuaries, v. 25, no. 1, p. 126-132.

Simonds, F.W., Swarzenski, P.W., Rosenberry, D.O., Reich, C.D., and Paulson, A.J., 2008, Estimates of nutrient loading by ground-water discharge into the Lynch Cove area of Hood Canal, Washington: U.S. Geological Survey Scientific Investigations Report 2008-5078, 54 p.

Smith, C.G., Cable, J.E., Martin, J.B., and Roy, M., 2008, Evaluating the source and seasonality of submarine groundwater discharge using a radon-222 pore water transport model: Earth and Planetary Science Letters, v. 273, p. 312-322.
Swarzenski, P.W., Burnett, W.C., Reich, C., Dulaiova, H., Peterson, R., and Meunier, J., 2004, Novel geophysical and geochemical techniques to study submarine groundwater discharge in Biscayne Bay, Florida: U.S. Geological Survey Fact Sheet 2004-3117, 4 p.

Swarzenski, P.W., Orem, W.G., McPherson, B.F., Baskaran, M., and Wan, Y., 2006, Biogeochemical transport in the Loxahatchee River estuary: The role of submarine groundwater discharge: Marine Chemistry, v. 101, p. 248-265.

Swarzenski, P.W., Reich, C.D., and Rudnick, D., 2008, Examining submarine ground-water discharge into Florida Bay by using ${ }^{222} \mathrm{Rn}$ and continuous resistivity profiling: U.S. Geological Survey Open-File Report 2008-1342, 74 p.

Swarzenski, P.W., Reich, C.D., Spechler, R.M., Kindinger, J.L., and Moore, W.S., 2001, Using multiple geochemical tracers to characterize the hydrogeology of the submarine spring off Crescent Beach, Florida: Chemical Geology, v. 179, p. $187-202$.

Swarzenski, P.W., Simonds, F.W., Paulson, T., Kruse, S., and Reich, C.D., 2007, A geochemical and geophysical examination of submarine groundwater discharge and associated nutrient loading estimates into Lynch Cove, Hood Canal, WA: Environmental Science and Technology v. 41, p. $7022-7029$.

Valiela, I., Costa, J., Foreman, K., Teal, J.M., Howes, B., and Aubrey, D., 1990, Transport of water-borne nutrients from watersheds and their effects on coastal waters: Biogeochemistry, v. 10, p. 177-198.

U.S. Census Bureau, 2009, State and county quick facts: http://quickfacts.census.gov 